\title{
Countercyclical Foreign Currency Borrowing: Eurozone Firms in 2007-2009*
}

\author{
Philippe Bacchetta \\ University of Lausanne \\ Swiss Finance Institute \\ CEPR
}

\author{
Ouarda Merrouche \\ University Paris-Nanterre \\ EconomiX
}

November 2019

\begin{abstract}
Using syndicated loan-level data we document and explain the causes and implications of a new and surprising stylized fact. In the midst of the financial crisis, dollar borrowing by leveraged Eurozone corporates rose dramatically relative to their euro borrowing. We show that this resulted from a shift from Eurozone to non-Eurozone banks, mainly US banks. This was combined with an increase in the proportion of dollar lending by non-Eurozone banks, explained by a rise in the relative cost of euro wholesale funding and the disruptions in the FX swap market. Non-Eurozone banks thus dampened the 2007-2009 credit crunch in Europe.
\end{abstract}

JEL classification numbers: G21, G30, E44

Keywords: Money market, swaps, credit crunch, corporate debt, foreign banks.

* We would like to thank Linda Goldberg, Steven Ongena, and Clemens Otto, as well as seminar participants at the New York Fed, the IMF, the World Bank, the Swiss National Bank, the University of Lausanne, University of Geneva, University Paris Dauphine, Aix-Marseille School of Economics, University of Zurich, and participants at the $1^{\text {st }}$ RELTIF conference held at Oxford University for helpful comments and suggestions. Financial support from the ERC Advanced Grant \#269573 is gratefully acknowledged.

Philippe Bacchetta is Swiss Finance Institute professor of economics at the Faculty of Business and Economics, University of Lausanne, Switzerland (Email: philippe.bacchetta@unil.ch). Ouarda Merrouche if professor of economics at the Faculty of Business and Economics, University of Paris-Nanterre, France (Email: ouarda.merrouche@eui.eu). 


\section{INTRODUCTION}

A wave of substantial financial disintegration has been observed during the recent financial crisis. While gross capital flows declined sharply in general (e.g., Broner et al., 2013), the decline has been particularly steep for banking flows among developed economies (Milesi-Ferretti and Tille, 2011). The literature shows evidence of a flight home effect in syndicated bank loans (Giannetti and Laeven, 2012a) and of financial protectionism in bank lending (Rose and Wieladek, 2014). We also observe that global banks have increased the use of their local currency in their lending (e.g., Ivashina et al., 2015). In this context it is surprising that dollar borrowing by many Eurozone (EZ) non-financial corporates increased dramatically from an average of 5 billion USD during 2004-2006 to a peak of 40 billion in 2008 (solid red line in Figure 1). While the proportion of dollar borrowing was about 5\% in 2004-2006, it increased to 35\% for noninvestment grade borrowers and to $15 \%$ for investment grade borrowers in the second half of 2008 (Figure 2). ${ }^{1}$ Importantly, we do not observe a similar pattern in bonds. The increase in dollar bond issuance was rather transitory (it lasted on average 1 quarter) and much smaller (4 percentage points for investment grade firms and 8 percentage points for non-investment grade firms).

[Figures 1 and 2 about here]

The purpose of this paper is to document this surprising episode in international banking flows and identify the factors that led to that development. We argue that the increase in dollar borrowing by EZ leveraged ${ }^{2}$ firms can be explained by the distinct reaction of EZ and US banks (the main foreign lenders in the EZ syndicated loan market) to the financial crisis. Moreover, 
these reactions are related to two main (and perhaps related) symptoms of the global financial crisis: the domestic credit crunch and the drying up of global interbank markets. Figure 1 depicts a high positive correlation between the amount of dollar debt issued by EZ corporates and an indicator of the tightness of the EZ credit supply. ${ }^{3}$

Our baseline sample includes quarterly syndicated loan issuances obtained from ThomsonReuters Dealscan for the period Q1-2004 to Q4-2009. We observe the nationality of lead lenders and the currency denomination of loans. In our baseline setting we define non-EZ banks as arrangers headquartered outside the EZ. Moreover, we define a non-EZ bank loan as a syndicated loan with at least one arranger bank located outside of the EZ; alternatively, we measure the participation of non-EZ banks by their percentage in a syndicate.

During the financial crisis, US banks partly replaced EZ banks in loans to riskier firms. A potential explanation is the difference in banking regulation. During this period and until 2014 US lenders operated fully under Basel I, while EZ banks were under Basel II. ${ }^{4}$ Under the Basel I framework, the risk weight on risky and safe corporate debt is the same. This means that US banks had greater incentive than EZ banks to load onto risky corporate debt as their capital position deteriorated due to subprime losses. ${ }^{5}$ Another difference for US banks is that they received capital support from the US government earlier than other banks. However, the first wave of capital injection took place in Q4-2008 which is later than the shift toward US credit and dollar borrowing we document.

Regarding the shift towards dollar, the explanation we test is that higher dollar borrowing during the EZ credit crunch results from the combined effect of an increase in the market share of non- 
EZ banks and an increase in the relative cost of funding in euro they face. In sum, the domestic credit crunch pushes risky firms to borrow from non-EZ banks and the coincident disruption in the euro interbank market pushes non-EZ banks reliant on wholesale funding away from lending in euro. We also show that an increase in the cost of swapping euro into dollar, caused by the drying up of unsecured dollar funding, leads EZ firms to increase their demand for foreign dollar credit.

We decompose our empirical analysis into three steps. In a first step, we verify that non-EZ banks' credit to riskier EZ firms is countercyclical: when EZ banks tighten lending standards, riskier borrowers are more likely to obtain a loan from a non-EZ bank rather than from a EZ bank. We find that this effect at the intensive and extensive margins is mostly attributable to US banks and that it is significant even when we account for changes in the stance of US monetary policy.

In a second step, we analyze the differences in the choice of currency between risky and safe borrowers during the credit crunch in relation to variations in the cost of funding in the euro interbank market (the Euribor-OIS spread) and the cost of swapping euro into dollar - the deviation from covered interest parity (the euro basis). The switch to dollar borrowing sourced from non-EZ banks is significant for risky firms in export-intensive sectors.

Third, we ask whether this matters in real terms: we assess the real effect of non-EZ banking using ordinary least squares and instrumental variables to correct for unobservable differences between borrowers with and without a non-EZ bank relationship. We report relevant statistical tests that validate our instruments. We find that non-EZ banking alleviates the financial 
constraints of EZ firms: during the credit contraction of 2007-2009, riskier EZ firms exposed to a weak EZ lender pay a lower spread on new loans issued and do not cut employment when they have also a prior relationship with a non-EZ bank. ${ }^{6}$

We specify a linear model with firm fixed effects for the choice among different sources of finance and among different currencies. The fact that we focus on within-firm shifts between different sources of finance and different currencies (i.e., compositional changes rather than levels) means that our results cannot be driven by changes in the population of firms tapping different forms of finance over time or by changes in the aggregate demand for debt. The effects we document are also for the same reason not related to changes over time in the capacity of firms to raise debt. One caveat is if firms decide to shift to foreign banks or foreign currency for reasons other than the drying up of credit at home. For example, they could shift the composition of their borrowing if foreign banks lend cheaper or if rates on dollar loans are lower than euro rates. To control for these alternative explanations, we include in our model a battery of indicators that capture credit conditions in the US and the stance of monetary policy in the US. Further, the fact that we focus on EZ countries means that our results cannot be driven by differences in the stance of monetary policy or nominal exchange rate expectations across countries.

\section{Literature Review}

There is a growing literature analyzing cross-border banking during the recent financial crisis (e.g., Cetorelli and Goldberg, 2011, Claessens, 2017). In particular, the evidence indicates that global banking flows amplify international credit cycles (e.g., Giannetti and Laeven, 2012b, 
Calderon and Kubota, 2012) so that foreign borrowing, typically in foreign currency, declines sharply in a credit crunch. ${ }^{7}$ This is also true for syndicated loans after the Lehman Brothers collapse (De Haas and Van Horen, 2012). The dampening impact of foreign lending that we document in this paper therefore contrasts with the existing evidence.

Our findings on the role of cross-border banks extend earlier work by Haselmann and Watchel (2011) and Bruno and Hauswald (2014). Haselmann and Watchel (2011) document that foreign banks (banks headquartered outside the borrower home country) play a prominent role in the syndicated loan market and that they lend more to riskier borrowers in developed markets. They however do not study the role of foreign banks during a crisis. Using country-level data, Bruno and Hauswald (2014) find a positive effect of foreign banks' presence on real growth and this effect is stronger during banking crises and in contexts where informational and legal frictions loom larger, hindering firms' access to credit. Our firm-level data allow for a better identification of the channel through which the presence of foreign banks alters firm performance during a crisis.

Our paper extends three other strands of literature: (1) on the reshaping of corporate financing during a credit crunch; (2) on the drivers of foreign currency credit; and (3) on the real effects of the 2007-2009 credit crunch. The first strand of literature includes Ivashina and Becker (2014) who find that EZ corporates increased their reliance on the bond market in response to the contraction of bank credit. Holmstrom and Tirole (1997) study the effect of a credit contraction on the forms of financing in a model where firms are heterogeneous in their net worth. In line with our results their model implies a differentiated response to shocks depending on credit 
quality. De Fiore and Uhlig (2015) develop a general equilibrium model with firms that differ in their risk of default that can replicate the aggregate shift from bank finance to bond finance witnessed in Europe since 2009. But these models do not allow for foreign bank lending as an alternative source of financing.

The literature on foreign currency borrowing or lending focuses on emerging markets in the context of financial crises. ${ }^{8}$ The empirical evidence shows that firms are more likely to borrow in foreign currency when they are exporters or with large cross-currency interest differentials (e.g., Keloharju and Niskanen, 2001, McCauley et al., 2015, Brown, Kirschenman and Ongena, 2014, Brown, Ongena, and Yeşin, 2011). However, there is little work on advanced economies. For the recent financial crisis, an exception is Ivashina et al. (2015) who find that EZ banks reduced their dollar lending.

The growing literature on the real consequences of the 2007-2009 credit crunch includes Chodorow-Reich (2013); Bentolila et al. (2018), and Haltenhof et al. (2014) who study the impact on employment; and Cingano et al. (2016) who also analyze the effect on investment. ${ }^{9}$ Like our paper, all these papers find a significant effect on employment exploiting micro (firm or industry) level data. But none of these papers studies the mitigating role of foreign banks which is the focus of this paper.

The remainder of the paper is organized as follows. Section 2 presents our data sources and gives a historical background of the twin crises in the credit market and in funding markets. Section 3 describes our two-step empirical approach, discusses the results, and evaluates the transmission 
channels. Section 4 reports an analysis of the real effect of the credit crisis and of the mitigating role of non-EZ banks. Section 5 concludes.

\section{BACKGROUND FACTS AND DATA}

This section documents our data sources and provides a descriptive analysis of the changing lending behavior of EZ and non-EZ banks during the credit crunch. We then provide a historical overview of the difficulties that EZ banks encountered as a consequence of large exposures to the US subprime meltdown and the associated freeze in the asset backed commercial paper (ABCP) market contaminating interbank and swap markets. Our model will then show that the coincident drying up of liquidity in euro wholesale funding markets or in swap markets creates the conditions for an increase in dollar borrowing relative to euro borrowing.

\subsection{The Role of non-Eurozone Banks and the Importance of Dollar Credit in the Eurozone}

\section{Syndicated Loan Market}

Our benchmark sample covers the quarterly syndicated loan issuance activity of EZ non-financial corporates. Back-of-the-envelope calculations reveal that syndicated loans are a significant source of financing for European firms, accounting for about a third of all financing at of the end

of our sample period. ${ }^{10}$ To understand the sharp increase in dollar borrowing during the 20072009 financial crisis we use data for the period 2004-2009. 
The data source for syndicated loans is Thomson-Reuters Dealscan. As is common in the literature, we consider loans to be issued by the lead arrangers. Syndicated loans are often subscribed by more than one lead bank, but we do not observe the contribution of each lead bank. As a proxy for the amount extended by non-EZ banks we calculate the proportion of non-EZ arrangers to the total number of arrangers in the syndicate, as is standard in the literature. Non-EZ loans are defined as syndicated loans underwritten by at least one lead arranger headquartered outside the EZ. Further, for each loan we observe the amount, the currency denomination, the spread to benchmark at issuance (partially populated), calculate the maturity of the loan in months, and can separate real investment purpose loans and loans raised for other purposes such as mainly refinancing and restructuring purposes (leveraged-buyouts, mergers and acquisitions). We include both term loans and credit lines. Our dataset is organized as a panel of firm-quarter observations with positive debt issuance. More than 25 percent of the loans issued in our sample are risky, i.e. rated below investment grade. ${ }^{11}$

[Table 1 about here]

Table 1 reports the number of borrowers by country. Out of 3594 firms with a positive demand for credit, 1511 firms borrow from non-EZ banks, and 307 firms issue dollar loans during our sample period. ${ }^{12}$ The number of borrowers is broadly proportional to country size. For the regressions, we consider firms that issue more than one loan during our sample period. There are 795 of these firms, of which 556 have ever borrowed from a non-EZ bank and 105 have borrowed in dollar. Table 2 gives the distribution of credit supplied by lender nationality before and during the credit crunch. In order to remove the effect of changes in the sample of firms 
tapping the market over time, we focus only on firms that borrow in both periods. We observe several interesting facts. First of all, US banks are the largest foreign participants in the EZ market. Second, unlike all other lenders, US banks have a larger participation in the leveraged segment of the market than in the investment grade segment of the market: $28 \%$ for leveraged loans against $9 \%$ for investment grade loans during the credit crunch, consistent with the fact that being under Basel I gives US banks a greater incentive to load onto riskier corporate debt. Third and most importantly, while EZ banks have reduced their participation in the leveraged segment of the market from $51 \%$ to $46 \%$ during the credit crunch, non-EZ banks, and most notably US banks, have increased their participation substantially from $49 \%$ to $54 \%$. Last but not least, for all non-EZ banks, but again most notably US banks, we observe a dramatic increase in the proportion of credit denominated in US dollar. During the crisis $42 \%$ of US banks' loans are in US dollars against $11 \%$ before the crisis.

\section{[Table 2 about here]}

These observations are confirmed at the level of individual banks, comparing the lending behavior of the same bank over time. In Table 3 we list the largest non-EZ lenders for which we calculate the percentage of their total lending (based on prorated figures) extended to risky EZ borrowers and the percentage of their total lending denominated in US dollar before and after the crisis. Overall, we see that US banks increase risk while UK and Japanese banks reduce risk during the credit crunch. And for all the banks we observe an increase in the percentage of lending denominated in US dollars, albeit stronger at US banks.

[Table 3 about here] 


\subsection{The 2007-2009 Financial Crisis in Europe}

The first signs of the eruption of the US subprime crisis in Europe date back to February 2007 when HSBC announced unexpected losses of 10.5 billion USD and fired the head of its US mortgage lending business. European banks were directly involved in the US subprime market. This is true of all important participants in the syndicated loan market like Deutsche Bank and French banks Société Générale and BNP Paribas. According to Acharya and Schnabl (2009), European banks, notably German, Dutch, Belgian, and French banks, were large sponsors of structured investment vehicles (SIV's) and conduits. This shadow business was heavily invested in US dollar denominated subprime assets, mainly financed through the issuance of asset backed commercial paper (ABCP) in US dollar. When the ABCP market came to an abrupt halt in August 2007, ${ }^{13}$ banks were forced to take assets from SIV's and conduits back on their balance sheets. As the value of US subprime assets plummeted, banks experienced large losses. The first banks that required support from their governments were not US banks but German banks IKS, Deutsche Industriebank, and Sachsen Landesbank. In August 2008 Bayern LB and IKB reported losses above 10 billion USD, more than what their capital position could support.

As losses depleted capital, European banks tightened lending standards, leading to a sharp decline in the volume of activity in the syndicated loan market. Figure 1 shows the net percentage of EZ banks that report having tightened their lending standard for large firms in the past 3 months,

average across all EZ countries. ${ }^{14}$ There are important variations in this indicator over the sample period from $-10 \%$ (loosening) at the 10th percentile to $42 \%$ (tightening) at the 90 th 
percentile. Variations across countries (not shown) are important as well with an earlier, more persistent, and deeper tightening of lending standards in southern EZ countries. Syndicated loan issuance activity declined rapidly and persistently across all EZ countries irrespective of the purpose of the debt issued.

Growing uncertainty about the extent of subprime assets banks held on their balance sheet, the magnitude of the losses, and whether banks had enough capital to bear these losses, spread the crisis immediately to interbank markets. Banks became increasingly reluctant to lend to each other due to mounting counterparty risk and fear about their own ability to raise funding in the future. The global interbank market crisis reached a state of panic when Lehman Brothers filed for bankruptcy in September 2008 and most unsecured sourced of funding eroded. Figure 3 depicts large spikes in the cost of funding in the euro and the dollar unsecured interbank markets measured by the difference between Euribor (or Libor USD) and overnight index swap spreads.

[Figure 3 about here]

The inability to roll-over ABCP funding then put pressure on the banks to find new sources of funding: being unable to raise dollar funding in the interbank market and facing growing needs to fund their dollar denominated assets European banks turned to foreign exchange swaps, a secured form of funding. The surge in the demand for exchanging euros for dollars --synthetic dollar funding-- combined with limited capacity on the part of arbitrageurs ${ }^{15}$ caused repeated deviations from covered interest parity. This is shown in Figure 4 which plots the deviation from CIP, the euro basis (the cost of synthetic dollar funding), computed using 3-month Euribor, dollar Libor and forward rates. ${ }^{16}$ Central banks liquidity injections and recapitalization plans adopted starting 
in Q4-2009 helped restore orderly conditions in funding and credit markets until the eruption of the sovereign debt crisis.

[Figure 4 about here]

\section{THE LENDING BEHAVIOR OF NON-EUROZONE BANKS DURING THE CREDIT CRUNCH}

The analysis focuses on non-investment grade firms, called Risky. Our explanation for the increase in dollar borrowing by Risky firms is based on the combination of two hypotheses. The Appendix provides the theoretical support for these hypotheses. First, the reduction in banks capital at the onset of the financial crisis leads to a Home credit crunch. This increases the market share of Foreign banks, so that Risky firms switch from Home to Foreign banks with a higher appetite for risk. Foreign banking may be associated with higher dollar borrowing. The second hypothesis is that the drying up of liquidity in euro wholesale markets leads Foreign banks to shift to dollar as they have low deposits in euro. Moreover, the drying up of liquidity in euro interbank markets and dollar swap market makes dollar borrowing more attractive, especially for those EZ firms that have a high share of foreign income. This amplifies the positive relationship that may exist between borrowing from Foreign banks and borrowing in dollar.

We test this explanation in two steps. First, we examine how the distribution of credit between EZ and non-EZ banks and its currency composition change during the credit crunch. Second, we analyze the (amplifying) effect of the disruption in funding markets on the currency composition 
of loans. We document these effects separately for non-EZ banks that presumably have large euro deposits and for other foreign banks (notably, US banks).

\subsection{The Shift to non-Eurozone Banks}

We use the following baseline regression:

$$
y_{i j t}^{1}=c^{1}+\theta_{i}^{1}+\gamma_{t}^{1}+\beta_{1} C C I_{j t}+\beta_{2} C C I_{j t} * R i s k y_{i t}+\beta_{3} R i s k y_{i t}+X_{j t} \beta_{4}+\varepsilon_{i j t}
$$

The left-hand side variable is the proportion of non-EZ banks in the syndicate. $C C I_{j t}$ is the net percentage of EZ banks that report in the ECB survey having tightened credit to large firms in the past three months. Importantly, according to the same survey banks tighten credit standards due to higher cost of capital and limited access to market funding, but never mention competition from foreign banks as a reason for tightening credit standards. ${ }^{17} \theta_{i}^{1}$ are firm fixed effects and $\gamma_{t}^{1}$ time fixed effects. ${ }^{18}$ Risky is a dummy that indicates whether the loan is rated below investment grade or not rated in a given quarter.

We are interested in identifying the effect of a reduction in the credit supply on the demand for non-EZ credit. Therefore we also include $X_{j t}$ which is a vector of variables that capture changes in the supply of non-EZ credit and in the demand for dollar: interaction terms of Risky with the US policy rate, the dollar/euro exchange rate change, the euro-dollar interest rate differential, a survey measure of changes in the US demand for bank credit, and a survey measure of changes in 
the domestic demand for bank credit and its interaction with Risky. ${ }^{19}$ Our estimates are not significantly altered if we do not include $X_{j t}$.

The inclusion of firm fixed effects is key to our analysis: it rules out the possibility that our results could be driven by changes over time in the composition of firms raising debt. And the fact that we focus on changes in the debt composition rather than the debt level means that we abstract from changes in the aggregate demand for debt. All the firms in our analysis have a positive demand for debt.

The coefficients of interest are $\beta_{1}$ and $\beta_{2}$ estimated by ordinary least squares (OLS). If non-EZ credit is countercyclical for riskier firms we should verify that $\beta_{1}+\beta_{2}>0$. We then check the robustness of our findings to using an alternative estimator that accounts for the presence of many zeros in our sample. ${ }^{20}$

[Table 4 about here]

The results of estimating equation (1) are reported in Table 4. Reported standard errors are clustered at country*year level. ${ }^{21}$ In column I, if we do not allow for a different effect of CCI between risky and not risky firms the effect of CCI is negative and not significant statistically or economically. In column II we allow for a different effect for risky and not risky firms which we find to be positive as expected but not significant statistically in the full sample. It is statistically and economically significant if we restrict the sample to real purpose loans, column III. This result may be attributable to the sharp decline in leveraged buyouts and mergers and acquisitions during the crisis, hence it may be more pertinent to focus on real loans as they are less likely to 
vary due to changes in demand. In other words, by focusing on real investment loans we address the concern that lending declined also because of a decline in the demand for restructuring loans. Indeed, firms scale back on expansion plans during a recession. Another issue may be that our results are driven by a change in the composition of loans by purpose over time. If the number of loans that tend to be more often extended by international syndicates increase over times then our estimates would be biased upward due to this compositional change. In Table A1 of the online Appendix we report the composition of syndicated lending by loan purpose, bank nationality and currency denomination. We observe that there is not much change in the composition of loans by purpose but, consistent with our interpretation, there is a significant shift to dollar which is bigger for categories with large proportions of foreign banks (with the exception of project finance). To further address this issue, we run a regression including loan purpose fixed effects in column IV. Our results are unaltered.

In terms of magnitude the shift to non-EZ banks is significant: an increase in CCI from the $10^{\text {th }}$ percentile to the $90^{\text {th }}$ percentile is associated with a 25 percentage point increase in the participation of non-EZ banks to real purpose loans. Also when we focus on US credit and eliminate non-US non-EZ loans from the sample, we find that US credit is countercyclical for both real and total loans, column V. An increase in CCI from the $10^{\text {th }}$ percentile to the $90^{\text {th }}$ percentile is associated with a 9 percentage point increase in the participation of US banks to syndicated loans extended to riskier borrowers. The estimate of $\beta_{1}$ which captures the effect on non-risky firms instead is small and statistically insignificant, meaning that on average US banks increase risk when EZ banks reduce risk. This is consistent with the fact that, since US banks operate under Basel I, when EZ banks retreat from the leveraged segment of the market US banks 
seize the opportunity to increase returns by shifting from safe to risky corporate loans, without consequences on their capital requirement. Instead, when we exclude US credit from the sample we find that non-US non-EZ credit is acyclical (not reported). In column VI we run a regression restricting the sample to the firms that had a pre-crisis relationship with a weak EZ bank, meaning they had borrowed in the 4 years preceding the crisis from a bank that had a leverage ratio below $3 \%$ or that received public capital injections during the crisis. ${ }^{22}$ We find an effect that is statistically significant and economically high. In contrast, for firms that did not have a relationship with a weak EZ bank we find the effect of $C C I$ to be insignificant (not reported). In other words, our findings are reasonable in that we find the effect of the credit crunch to be significant only for the exposed firms.

\subsection{The Shift to Dollar}

To see whether the credit crunch alone caused a significant shift to dollar funding, we estimate an equation as in (1) but with the dependent variable being the proportion of debt issued in dollar by a given firm in a given quarter. Since we have very few observations lying between 0 and 1 (most firms borrow in either currency but not both) we then focus on the probability of borrowing a positive dollar amount and report estimates from a linear probability model (LPM) as well as a graphical representation of the interaction effect of interest using a logit estimator. Since our prior is that the shift to dollar is explained by the shift to non-EZ banks, for now we focus on the subsamples for which we found the shift to non-EZ banks to be significant statistically: the 
sample of real purpose loans (less affected by shifts in demand) and the sample of loans with a US bank participation.

\section{[Table 5 about here]}

The OLS results are reported in Table 5 columns I and II. We find $\beta_{1}+\beta_{2}$ to be positive and statistically and economically significant for real purpose loans ${ }^{23}$ (column I) and for loans with a US bank participation (column II). We report separate results for the sample of loans to which US banks participate because we suppose that US banks have small euro deposits: if they lend more to European corporates, this increase in lending is more likely to be associated with a shift to dollar. This shift would allow keeping currency risk and the associated capital requirement low. In column II, an increase in CCI from the $10^{\text {th }}$ percentile to the $90^{\text {th }}$ percentile is associated with a 25 percent increase in the proportion of newly issued US loans denominated in dollar.

In column III, we check whether our results are sensitive to adding loan purpose fixed effects to equation (1). This is again to address the concern that firms that have a relatively high demand for loans during the crisis may get loans that are more often arranged by international syndicates and dollar denominated, for some reason we ignore. The results are barely affected. In columns IV to VI we report estimates for the probability of borrowing in dollar. The results are robust: $\beta_{1}+\beta_{2}$ is confirmed to be positive and statistically significant at the $5 \%$ level for real purpose loans and for loans with a US bank participation. And the point estimates are larger if we exclude from the sample loans with only EZ bank participation (not reported).

We run two important robustness checks to further support our interpretation of the results. First, we test whether other firm characteristics could account for the shift to non-EZ banks and to 
dollar denominated loans. This reduces considerably our sample to the sample of firms that are matched to Amadeus, the database containing additional firm characteristics. Descriptive statistics of the additional characteristics are reported in Table A2 of the online appendix. We consider profitability, firm size, leverage, collateral, cash. The regression results including these additional characteristics are shown in Table 6. Risky stands out as the only firm characteristic that contributes to explain the shift to both non-EZ banks and to dollar during the crisis. In columns I and II we just replicate our baseline analysis in the reduced matched SDC-Amadeus sample for the percentage of foreign banks and the percentage of dollar borrowing. The results are rather stable. Then in columns III and IV we augment the baseline regression with the additional firm characteristics we have collected. Again the results are unchanged: our indicator of firm risk Risky interacted with CCI is significant while the other firm characteristics have insignificant statistical and/or economic effects, notably during the crisis. In columns V and VI we use leverage as an alternative measure of firm riskiness and find it to be as relevant as Risky and more relevant than other firm characteristics. We prefer using the indicator Risky because it is available for all firms in Dealscan, while leverage is only observed for the few firms for which we have balance-sheet data.

\section{[Table 6 about here]}

Second, we explicitly test whether it is the bank nationality or other bank characteristics that matter in explaining whether a bank lends more to risky firms during the crisis. For instance, it could be that bank nationality proxies for bank health. To this end, we collect additional bank characteristics from Bankscope measuring capital, funding structure, asset quality, bank size. The 
sample covers 51 banks that have a significant participation in the European syndicated loan market. Descriptive statistics are reported in Table A3 of the online appendix separately for EZ and non-EZ banks: non-EZ banks appear healthier than EZ banks along some but not all characteristics, for some measures of funding structure and asset quality EZ banks are on average healthier. This is true whether we consider average characteristics over the sample period or in 2006 (pre-crisis). Hence nationality appears to be a poor proxy of bank health.

[Table 7 about here]

To confirm the relevance of nationality against other bank characteristics we run bank-year level regressions where the dependent variable is either a bank percentage of lending to risky firms or the proportion of its lending that is denominated in dollar. The results are shown in Table 7. All time-varying bank characteristics are lagged one year. In column I we find that for the crisis period the non-EZ bank dummy is the only variable that is robustly and significantly (economically) associated with an increase in lending to risky firms. In column II we confirm that this effect is mainly driven by US banks. It is much weaker for UK banks and Japanese banks. In columns III and IV, the dependent variable is the \% of a bank lending in dollar. Again, the large shift to dollar during the crisis is driven by nationality and not by other bank characteristics, and it is stronger at US banks. Bank size matters as well, but its effect is economically much smaller. A one standard deviation increase in log assets is associated with a 3.5 percentage point increase in the proportion of lending denominated in dollar during the crisis. The shift to dollar is greater if the dependent variable is the percentage of lending in dollar to risky firms, column V. In Table 4 of the online Appendix we report a robustness exercise using the interaction of bank 
characteristics with $C C I$ instead of a crisis dummy. That implies using data by bank and country because unlike the crisis dummy CCI varies across countries as well. This does not change anything to our conclusions. All in all, it does not matter how we do it, our results are very stable and show that the only bank characteristic consistently explaining the changes we document is bank nationality.

The role of bank nationality could be explained by the fact that non-European banks are more exposed to a drying up of wholesale funding because they cannot easily substitute interbank funding by deposits. Data on non-European subsidiaries show that they have a much lower access to euro deposits to finance their euro assets. For example, in 2006, the deposit to asset ratio was 0.30 for non-European banks compared to 0.44 for European banks. ${ }^{24}$ We do not have data on branches since they do not report separate accounts from their parent bank, but there are various reasons why it is more difficult for foreign branches to raise local deposits. First, non-European branches do not participate in the deposit insurance scheme of EZ countries. ${ }^{25}{ }^{26}$ Further, deposits in foreign branches of US banks do not quality for US deposit insurance. ${ }^{27}$ Second, nonEuropean branches do not have access to the ECB liquidity facilities. ${ }^{28}$ For these important reasons it is plausible to expect non-European banks, chiefly US banks, to shift away from euro more and to a greater extent if they have entered the European market by opening branches rather than subsidiaries.

To test this hypothesis, we collected the number of branches and subsidiaries located in Europe for each non-EZ bank in our sample (see Table A5 of the online appendix) and examine the impact on dollar borrowing of the proportion of subsidiaries. The results reported in Table 8 
confirm that the shift to dollar is indeed greater for non-EZ banks with a higher proportion of branches. ${ }^{29}$ All in all, these results are in line with our conjecture that the shift to dollar is significantly channeled through a shift to banks that are both non-EZ and non-European.

[Table 8 about here]

\subsection{Transmission Channels}

We further develop the analysis of the channels through which dollar borrowing rises. First, we test the hypothesis that the domestic credit crunch was associated with a higher increase in spreads paid by riskier firms borrowing from EZ banks only compared to firms borrowing from non-EZ banks. Hence, the shift to non-EZ banks is significant also at the intensive margin. Second, we show that the rise in dollar borrowing during the credit crunch is significant in the full sample once we account for the amplifying effect of the drying up of liquidity in the euro interbank market. Third, we assess the extent to which the effect of the credit crunch on the composition of risky corporate debt is driven by good firms shifting from loans to bonds.

\subsubsection{Borrowing costs}

So far we have implicitly assumed that risky firms switch to foreign loans because domestic loans are becoming more expensive and not because foreign loans are becoming cheaper due to

confounding factors. A competing interpretation for $\beta_{2}$ being positive is that non-EZ loans 
become more attractive independently of the deterioration of the EZ supply of credit. For example, non-EZ loans may become more attractive if the cost of funding of non-EZ banks falls relative to the cost of funding of EZ banks due to looser monetary policy abroad. We have already addressed this issue somewhat by controlling for the interaction of Risky with the US monetary policy rate.

To check this further, let $i_{i t}^{f R}$ and $i_{i t}^{f N R}$ be the foreign cost of credit for risky and non-risky firms. We want to test whether

$$
\frac{d\left(i_{i t}^{f R}-i_{i t}^{f N R}\right)}{d C C I_{j t}}<0
$$

that is, whether the difference in the cost of foreign credit between risky and safe borrowers varies negatively with $C C I$, indicating a positive correlation of $C C I$ with heightened search for yield among foreign lenders. We want also to test whether, for the domestic banks, the difference in the cost of credit between risky and safe borrowers varies positively with CCI. This would indicate a drying up of credit for risky borrowers that is significant at the intensive margin and more so when firms are only reliant on domestic banks. For this we estimate equation (1) with the all-in-drawn spread to benchmark as dependent variable for non-EZ loans and EZ loans separately. We extend the list of control variables to include loan characteristics: issue size, currency denomination, maturity, an issue type dummy and a loan purpose dummy. The other control variables are as previously defined. Here too the inclusion of firm fixed effects is important since otherwise, because of flight to quality, spreads across periods would not be comparable. 
The results are reported in Table 9. In column I for non-EZ loans the correlation between $C C I_{j t} * R_{i s k} y_{i t}$ and the cost of debt is nil, while in column II it is positive and statistically significant for EZ loans as one would expect. We can therefore more firmly confirm that riskier borrowers shift to non-EZ banks because they are more financially constrained at home and not because foreign credit becomes more attractive.

[Table 9 about here]

In sum, we find our story consistent with the data: non-EZ banks somewhat contribute to absorb the shock for those firms that suffer most from the reduction in the EZ credit supply.

\subsubsection{Funding costs}

To analyze the role of funding costs, we consider the following specification which we run on the sample of quarters when EZ banks tighten credit standards $(C C I>0)$ :

$$
y_{i j t}^{2}=c^{2}+\theta_{i}^{2}+\delta_{1} R P_{t}+\delta_{2} R P_{t} * R i s k y_{i t}+\delta_{2} R i s k y_{i t}+\delta_{3} X_{j t}+\varepsilon_{i j t}
$$

where $y_{i j t}^{2}$ is a dummy for borrowing in dollar. $R P_{t}$ is either the euro interbank risk premium, or the dollar interbank risk premium, or the Euro basis. The other variables are defined as in equation (1). Again our estimates are not significantly altered if we do not include $X_{j t}$.

In Table 10 we report estimates of $\delta_{1} \cdot{ }^{30}$ As predicted by our model, we find that an increase in the Euribor-ois spread (ERP) amplifies the shift to dollar during the crisis. A 100 basis point increase in ERP is associated with a 17 percentage point higher probability that a risky firm 
borrows in dollar compared with a non-risky firm, column I. In column II, an increase in the dollar interbank risk premium has no effect. This can be explained by the fact that US banks have abundant dollar deposits which they can use to substitute for a fall in dollar wholesale funding. In column III we find that an increase in the euro basis of 100 basis points is associated with a 19 percentage points higher shift to dollar for riskier firms. The results are stable if we control for loan purpose fixed effects, in column IV.

\section{[Table 10 about here]}

So far we have conjectured that the underlying mechanism through which ERP leads to a shift to foreign currency is that banks facing increased pressure in euro funding reduce their supply of euro credit relative to dollar credit. To check this supply effect more directly we estimate the pass-through of ERP on lending rates of euro denominated loans using equation (2). The dependent variable now is the all-in-drawn spread to benchmark. The results are reported in Table 11.

\section{[Table 11 about here]}

In column I, we see that an increase in ERP causes an increase in the lending rate to risky firms for all banks. Now if we separate EZ loans only (column II) and loans with a non-EZ bank participation (column III), we find the pass-through of the funding cost to the lending rate to be significant for both sub-sample but slightly bigger for the sample of non-EZ loans.

\subsubsection{Loan-to-bond substitution}


Ivashina and Becker (2014) have shown that during periods of tight lending standards, US investment grade corporates shift from bank credit to the bond market. They conclude from this that the aggregate loan-to-bond substitution can be interpreted as alternative measure of contraction in credit supply.

In our context, investment-grade firms shifting from loans to bonds is another possible channel through which the credit crunch might affect the composition of risky corporate debt. ${ }^{31}$ To assess the importance of this channel in explaining the rise in dollar borrowing we first replicated the analysis of Ivashina and Becker and did find a significant relationship between CCI and the choice of bonds versus loans. We then replicated Tables 4 and 5 using instead of $C C I$ the fraction of firms which used bond finance among those firms that tap only one type of financing in each quarter, but found estimates that were insignificant. In sum, in this context, the aggregate loan-tobond substitution is significant but does not explain why risky corporates access non-EZ banks more and why they borrow more in dollar during the credit crunch.

\subsection{Additional Robustness Checks}

Due to the presence of many zeros in our sample we then run a fractional logit model developed by Papke and Wooldridge $(1996,2008)$ for proportion data. This model captures non-linear relationships, especially when the outcome variable is near 0 or 1 . This non-linear model is however not our preferred model for two reasons: first it does not accommodate our large number of fixed effects and second, interpreting interaction effects in non-linear models is far from straightforward. Indeed, in non-linear models, marginal effects provide no information about 
interaction effects (Ai and Norton (2003)). ${ }^{32}$ Green (2010) explains how to use simple graphical devices to depict interaction effects in non-linear models. Following his approach, Figure 5 depicts the interaction effect of $C C I$ and Risky in the fractional logit model: the relationship between the predicted fraction of non-EZ lenders and CCI, separately for risky and not risky firms. The distance between the two curves gives the interaction effect between CCI and Risky. At high levels of CCI up to $45 \%$ of the risky firms' borrowing is predicted to be from non-EZ banks, against less than $12 \%$ for not risky firms. This distance between the two curves increases as CCI increases and it is economically and statistically significant as the two confidence intervals do not overlap hence confirming our findings so far using a linear model. ${ }^{33}$

[Figure 5 about here]

Figure 6 shows the interaction effect of $C C I$ with risky from a logit model where the dependent variable is a dummy for dollar borrowing. We see that the predicted probability of dollar borrowing is significantly higher for the risky firms and more so at higher levels of CCI confirming OLS estimates. The marginal effects for the non-interacted terms are not significant and are reported in the online Appendix Table A9. We also replicated Tables 4 and 5 using a crisis dummy instead of $C C I$ and the results were broadly confirmed. ${ }^{34}$ Note that when both the dependent and the explanatory variables are dummy variables, a linear and non-linear model deliver the same results.

[Figure 6 about here]

Figure 7 depicts the effect of the interaction between ERP and the dummy for risky firms on the predicted probability of dollar borrowing. As ERP rises the distance in probabilities between 
risky and not risky increases and is statistically and economically significant hence confirming the OLS estimates.

[Figure 7 about here]

We ran several additional unreported robustness checks. First, we ran weighted least squares based on loan size and obtained similar results with often larger point estimates. This means that our results are not driven by a higher number of small value loans but hold also for large and very large loans.

Second, we re-estimated all equations controlling for trade credit and its interaction with Risky measured at country and sector level. Trade credit and bank credit are linked. A reduction in domestic bank credit might cause an increase in trade credit as firms delay payments to providers. In that case trade credit is a substitute to bank credit. On the other hand, during a severe credit crunch, good firms experiencing a decline in credit could cut trade credit to bad firms. It is therefore unclear a priori in what direction controlling for trade credit will affect our estimates. We used two alternative data sources, the BACH database ${ }^{35}$ and Amadeus Bureau van Dijk, ${ }^{36}$ which report accounts payable scaled by total sales as the measure of trade credit. Although we lose more than a fourth of our sample due to data being unavailable for some countries and/or some sectors, our results are barely altered.

We also analyzed the shift from bank to bond finance and found that for risky firms bond finance $^{37}$ is procyclical while for investment grade firms it is countercyclical. Investment grade firms could issue euro bonds as substitutes for euro loans, while risky firms could only tap on foreign currency credit sourced from non-EZ banks. 
A third robustness exercise we ran is to modify our definition of domestic banks to include only banks headquartered in the same country as the borrower. This means that we reconsider the assumption that the EZ credit market is fully integrated. If we do that we continue to find that extra-EZ credit is countercyclical but that credit from non-domestic EZ banks is procyclical and that non-domestic EZ credit does not shift significantly toward dollar, which confirms that our original definition of a domestic bank is more pertinent.

Fourth, our results are robust to the inclusion of alternative measures of the stance of EZ and US monetary policy. The stance of monetary policy at home can differ across EZ countries due to differences in inflation rates and this might cause banks to take more risk in some EZ countries than in others. Controlling for the real interest rate therefore allows isolating the effect of variations in domestic banks' credit policy solely due to shocks to their capital position. In addition, we included the US long term rate interacted with Risky to account for the main channel through which US unconventional monetary policies implemented since late 2008 could augment risk taking by US banks. The fact that we found that changes in the stance of US monetary policy do not explain the increase in risk taking by US banks supports our conjecture that regulatory capital arbitrage played its role.

All in all, we find that a twin crisis in the credit market and in funding markets explains the dramatic shift from euro credit to dollar credit observed for low-credit-quality EZ borrowers in 2007-2009. This shift to dollar is not channeled through a decline in trade credit or caused by the softening of US monetary policy. 


\section{REAL EFFECT OF NON-EUROZONE BANKING DURING THE CREDIT CRUNCH}

We test the real benefit of using a foreign bank relationship during the credit crunch. We follow in spirit Chodorow-Reich (2013) and estimate the effect of being exposed to a weak bank before the crisis on the change in employment between 2008 (peak) and 2010 (trough). We then extend his analysis by examining the mitigating effect of foreign banking measured by the percentage of non-EZ banks in the last pre-crisis loan syndicate. One issue is the possibility that firms that can build a relationship with a foreign bank perform better, grow faster, be less exposed to the domestic cycle. In this case, our estimate of the effect of foreign banking on employment will be biased upward. We can also imagine that weaker firms are more pressured to multiply banking relationships and borrow from abroad. It is therefore unclear in what direction our estimates will be biased.

To address the possible endogeneity of foreign banking, we apply an instrumental variables approach using as instruments the propensity of the last pre-crisis loan arranger(s) to co-syndicate with non-EZ banks. We report first-stage F-statistics and over-identification test statistics that validate our instruments. We also report a standard test of weak instrumental variables which supports the hypothesis that the instruments we use are strong predictors of foreign banking.

The baseline regression for the change in employment $E$ reads:

$$
\Delta E_{i j}=\delta_{j}+\theta_{s}+\mu_{1} \text { Weak bank }_{i}+\mu_{2} \text { Weak bank }_{i} * \% \text { foreign bank }_{i}+X_{i} * \mu_{3}+\varepsilon_{i j}
$$


which we estimate separately for risky and non-risky firms. $\delta_{j}$ and $\theta_{s}$ are country and industry fixed effects. $X_{i}$ is a vector of variables which controls for credit demand (cash holdings before the credit crunch, whether the last pre-crisis debt issued was a credit line rather than a term loan or a bond, and whether the firm has a debt maturing during the credit crunch), access to the bond market, and other relevant firm characteristics (total assets and age).

To estimate regressions (3) we hand-matched the Dealscan with the Bureau van Dijk Amadeus data which contains the number of employees by firm and firms' balance sheet data. We could exactly match 691 firms and after eliminating firms that reported zero total assets in 2007, we were left with a sample of 450 firms. We cover $12 \mathrm{EZ}$ countries and 23 sectors. Of these 450 firms $25 \%$ issue risky debt, and 288 firms have a relationship with a non-EZ bank. The growth rate of employment $\frac{E_{i}^{2010}-E_{i}^{2008}}{E_{i}^{2008}}$ is on average $-2.5 \%$, with large variations, the $10^{\text {th }}$ percentile is $32 \%$, after winsorizing the data at the $1 \%$ and $99 \%$ level.

Before we present the results from estimating equation (3), we report that our measure of exposure to the credit crunch $R_{i s k y} *$ Weak bank $k_{i}$ is relevant. Risky $*$ Weak bank $k_{i}$ captures the exposure of firm $i$ to the credit crunch: it is the interaction between the firm credit quality (risky or not risky) in 2007 and a dummy for having a pre-crisis relationship with a weak bank based on the last pre-crisis syndicate.

We estimate the effect of $\operatorname{Risky}_{i} * w_{e} a k_{i}$ on a dummy that indicates whether a firm borrowed during the Q3-2007/Q4-2009 credit crunch (ACCESS) and the difference in the average rate it paid during the credit crunch with the rate it paid on its last pre-crisis loan. Therefore, the sample 
covers firms that borrowed before the credit crunch going back to 2003. The results are reported in Table 12 including a full range of pre-crisis loans characteristics, fixed effects for the year of the last pre-crisis loan, borrower industry and country fixed effects, and controls for the demand for credit (bond market access and a dummy for whether a debt matures during the crisis). What we find is that higher exposure to the credit crunch is associated with a 10.6 percent lower probability of obtaining a loan during the crisis.

\section{[Table 12 about here]}

The decline in credit is also significant at the intensive margin with more exposed firms paying on average a spread 238 basis points higher that pre-crisis (column II). In column III conditional on obtaining a loan, non-EZ banks participation is 10 percent higher when EZ bank relationships are weak.

[Table 13 about here]

We now turn to the results of estimating equation (3), reported in Table 13. In column I the credit crunch captured by $R i s k y_{i} *$ Weak bank $k_{i}$ affects employment growth negatively. Then we run separate regressions for risky and non-risky firms to estimate the mitigating effect of having a non-EZ bank relationship which we capture with the interaction term Weak bank $k_{i}$ $\%$ foreign bank. First, in columns II and III we show that relying more on non-EZ banks does not make a difference on average. It makes a difference only for risky firms exposed to weak EZ banks. This is shown in column IV: for risky firms exposed to a weak EZ bank, having a non-EZ bank relationship curbed the decline in employment during the crisis. For non-risky firms, non- 
EZ banks have no role as these firms are not exposed to the credit crunch (column V). The 2SLS (columns VI and VII) estimates are larger. We report a first-stage F-statistic above 10 and the Hansen J-statistic cannot reject exogeneity of our instruments.

Fully non-EZ banked exposed firms do not reduce employment while exposed firms fully reliant on EZ banks reduce employment by up to $33 \%$. This effect encompasses not only the effect of obtaining a loan but also the effect of a decline in the amount of credit, the effect of an increase in the spread, shorter maturities, as well as the effect of uncertainty of future credit availability given labor adjustment costs.

\section{CONCLUSION}

The increase in dollar borrowing by non-investment grade EZ firms in the recent financial crisis is a puzzling phenomenon. In this paper, we propose an explanation that is consistent with the empirical analysis. The existing literature emphasizes a set of factors determining the currency denomination of debt, mainly the borrower's export intensity or foreign currency income and the interest rate differential between domestic and foreign currency loans. In this paper we have shown that during a liquidity crisis other factors also matter: an increase in the relative cost of funding in euro, which reduces the supply of credit by domestic lenders and curbs the willingness of foreign lenders to bear currency risk, causes a shift to foreign currency credit. This is true provided that foreign credit is countercyclical. We show that this was the case in Europe during the period 2007-2009, so that non-EZ banks had a stabilizing role. 
The way bank capital is regulated appears to play an important role in the process. The fact that US banks operated under Basel I meant that they had an incentive to shift to riskier corporate loans when EZ banks retrenched. Our analysis is therefore consistent with the view that the move from Basel I to Basel II with risk-sensitive capital requirements has contributed to amplify the credit cycle. Basel III goes some way towards addressing the problem through the introduction of mandatory buffers, a capital preservation buffer and a countercyclical buffer, that are built-up in good times and can be released in bad times to avoid a credit crunch.

Since 2009 the rise in offshore dollar credit has spread to emerging markets. This expansion, however, has not been fueled by a domestic credit crunch, but rather by low US interest rates. Contrary to the EZ experience in 2007-2009, this increase in foreign currency credit has been procyclical and may threaten financial stability as it stimulates credit booms. The financial systems in these countries are then vulnerable to sudden withdrawals, exchange rate risk, and sudden rises of foreign interest rates.

\section{APPENDIX: THEORETICAL FRAMEWORK}

The objective of this appendix is to provide a framework to structure the empirical analysis. To explain the increase in foreign currency borrowing, we propose an explanation in two steps. In the first step, we consider the switch by riskier firms from EZ to foreign, mainly US, banks. In the second step, more export-oriented firms switch from Home to Foreign currency borrowing with disruptions in the Home money market and the FX swap market. 


\section{A.1 Shift to More Risky Loans by Foreign Banks}

Consider a simple framework where Home firms can borrow from Home and Foreign banks. Firms differ in their exposure to exchange rate risk and in their overall credit riskiness for lenders. For simplicity assume that there are two levels of credit riskiness, Risky and Not Risky, and that credit risk is not correlated to exchange rate risk. The focus is on Risky firms as they are dependent on bank loans, while Not Risky firms can find alternative sources of financing. Moreover, Risky firms have more impact on the riskiness of banks portfolios and are more likely to be affected by shocks to banks' capital or changes in capital regulation. ${ }^{38}$ Risky firms receive a proportion of $N_{t}$ Home bank loans and $N_{t}^{*}=1-N_{t}$ Foreign bank loans.

We assume that a negative shock to capital has a distinct impact for Home and Foreign banks because of a different regulatory environment. Home banks are more risk averse as they are under Basel II, while Foreign banks are under Basel I. ${ }^{39}$ Home banks reduce their risk-weighted assets and thus reduce lending to Risky firms. This is not the case for Foreign banks, so they can substitute Home banks in lending to Risky firms. ${ }^{40}$ In other words, a negative capital shocks leads to a decline in $N_{t}$, and an increase in $N_{t}^{*}$. This can be summarized in the following hypothesis to be tested:

\section{HYPOTHESIS 1. In the 2007-2009 credit crunch, the most risky firms switched from Eurozone to Foreign banks, especially US banks.}

\section{A.2 Shift to Foreign Currency Loans}

Bank loans can be either in euros, the Home currency, or in dollars, the Foreign currency. The spot exchange rate in euro per dollar at time $t$ is $S_{t}$. Firms decide the currency of their loan based on risk and on the expected borrowing cost. The interest rate charged by banks to firms in euro is $i_{t}^{E}$ and the one in dollars is $i_{t}^{D}$. Changes in $i_{t}^{E}$ and $i_{t}^{D}$ are directly affected by money market rates, where banks get their marginal funding. We assume that Home (Foreign) banks have an advantage in borrowing in euros (dollars) ${ }^{41}$ so that in equilibrium Home banks only lend in euros, 
while Foreign banks lend both in euros and dollars. The proportion of loans in dollars is denoted by $D_{t}$. Foreign banks thus lend $D_{t}$ in dollars and $1-N_{t}-D_{t}$ in euros.

Firms can also borrow in dollars and hedge through the forward or swap market, using the forward rate $F_{t}$. When Covered Interest rate Parity (CIP) does not hold, hedged dollar borrowing will differ from euro borrowing. We define the deviation from CIP expressed in dollar, or the euro basis, as $\Delta_{t}=\left(S_{t} / F_{t}\right)\left(1+i_{t}^{E}\right)-\left(1+i_{t}^{D}\right)$. Overall, we can denote the proportion of loans in dollars to Risky firms as $D=D\left(i^{E}, i^{D}, \Delta\right)$, where $D$ increases with $i^{E}$ and $\Delta$ and decreases with $i^{D}$. We present below a simple model deriving $D\left(i^{E}, i^{D}, \Delta\right)$ and show that the increase in dollar borrowing comes from more export-oriented firms. This leads to the following testable hypothesis:

\section{HYPOTHESIS 2. When host country interbank markets or the FX swap market dry up, more export-oriented risky firms increasingly borrow in dollars.}

\section{A.3 Modeling Foreign Currency Borrowing}

Let us abstract from time subscripts and assume that the current exchange rate is equal to one. We denote by $S$ the next period exchange rate. We also assume that price levels are equal to one in each currency and that $y$ is the total output level identical to all firms. There is a continuum of firms indexed by $i$. A proportion $\lambda_{i}$ of output is sold in euros and 1- $\lambda_{i}$ in dollars. Firms with low $\lambda_{i}$ will thus be considered as export-oriented firms. We assume that $\lambda_{i}$ is uniformly distributed so that $\lambda_{i} \in[0,1]$. The income of firm $i$ is

$$
y_{i}=\left(\lambda_{i}+\left(1-\lambda_{i}\right) S\right) y
$$

where $S$ is the only random variable and is assumed to be normally distributed $N\left(1, \sigma^{2}\right)$. We also assume that $y=1$.

Home firms need to borrow for production. Due to transactions costs, firms have only one loan contract in either currency. Therefore, firms choose the currency that gives them the higher 
expected utility. We assume that firms derive utility from their profits, $U\left(\Pi_{i}\right)$ and that the utility function is exponential, so that they have mean-variance preferences. We denote by $\Pi_{i}^{E}, \Pi_{i}^{D}$, and $\Pi_{i}^{D H}$ the profits with borrowing in euros, in unhedged dollars and in hedged dollars. These are:

$$
\begin{gathered}
\Pi_{i}^{E}=y_{i}-\left(1+i^{E}\right) \\
\Pi_{i}^{D}=y_{i}-S\left(1+i^{D}\right) \\
\Pi_{i}^{D H}=y_{i}-S\left(1+i^{D}\right)-(F-S)\left(1+i^{D}\right)=y_{i}-F\left(1+i^{D}\right)
\end{gathered}
$$

where the last term in $\Pi_{i}^{D H}$ is the forward contract (assuming full hedging). When CIP holds and abstracting from transactions costs, $\Pi_{i}^{E}=\Pi_{i}^{D H}$ (as $\left.F\left(1+i^{D}\right)=1+i^{E}\right)$.

Firms prefer borrowing in dollars if this gives a higher expected utility than borrowing in euros, i.e., $E U\left(\Pi_{i}^{D}\right)>E U\left(\Pi_{i}^{E}\right)$. With mean-variance preferences, firm $i$ prefer borrowing in dollars if:

$$
E\left(\Pi_{i}^{D}\right)-\frac{\gamma}{2} \operatorname{Var}\left(\Pi_{i}^{D}\right)>E\left(\Pi_{i}^{E}\right)-\frac{\gamma}{2} \operatorname{Var}\left(\Pi_{i}^{E}\right)
$$

which is equivalent to:

$$
i^{E}-i^{D}+\frac{\gamma}{2}\left[2\left(1-\lambda_{i}\right)-\left(1+i^{D}\right)\right]\left(1+i^{D}\right) \sigma^{2}>0
$$

This implies that the more export-oriented firms with $\lambda_{i}<\lambda^{*}$ prefer borrowing in dollars, where the threshold $\lambda^{*}$ is given by:

$$
\lambda^{*}=\frac{1-i^{D}}{2}+\frac{i^{E}-i^{D}}{\left(1+i^{D}\right) \gamma \sigma^{2}}
$$

Since $\lambda_{i}$ is distributed uniformly over [0,1], $\lambda^{*}$ also represents the aggregate demand for dollar borrowing. The first term in $\lambda^{*}$ is the level below which borrowing in dollars reduces risk: only highly export-oriented firms find it optimal to borrow in dollars. The second term is simply determined by the differential cost of borrowing. If $i^{E}>i^{D}$, more firms prefer borrowing in dollars. When $\gamma \sigma^{2}$ is higher, firms find it more useful to borrow in dollars despite the higher cost. 
If $i^{E}$ increases, the more export oriented firms that borrow in euros ( $\lambda_{i}$ higher but close to $\lambda^{*}$ ) will switch to borrow in dollars.

Moreover if CIP does not hold so that $\Delta>0$, firms will start switching from euro to dollar borrowing (as $\Pi_{i}^{E}<\Pi_{i}^{D H}$ ). The extent of this switch will depend on transaction costs, that we do not model here, but not on export orientation. Therefore we can write $D=D\left(i^{E}, i^{D}, \Delta\right)$.

\section{LITERATURE CITED}

Acharya, Viral V., Tim Eisert, Christian Eufinger, and Christian Hirsch. (2018) "Real Effects of the Sovereign Debt Crisis in Europe: Evidence from Syndicated Loans.” Review of Financial Studies 31, 2855-2896.

Acharya, Viral V., and Philipp Schnabl. (2009) "Do Global Banks Spread Global Imbalances: Asset-Backed Commercial Paper during the Financial Crisis of 2007-09.” IMF Economic Review 58, 37-73.

Aghion, Philippe, Philippe Bacchetta, and Abhijit Banerjee. (2004) "A Corporate Balance-sheet Approach to Currency Crises.” Journal of Economic Theory 119, 6-30.

Ai, Chunrong, and Edward C. Norton. (2013) "Interaction Terms in Logit and Probit Models." Economics Letters 80, 123-129.

Angrist, Joshua D., and Jörn-Steffen Pischke. (2009). Mostly Harmless Econometrics. Princeton, Princeton University Press. 
Aramonte, Sirio, Seung Jung Lee, and Viktors Stebunovs. (forthcoming) "Risk Taking and Low Longer-term Interest Rates: Evidence from the U.S. Syndicated Loan Market.” Journal of Banking and Finance.

Becker, Bo, and Victoria Ivashina. (2014) “Cyclicality of Credit Supply: Firm Level Evidence.” Journal of Monetary Economics 62, 76-93.

Behn, Marcus, Rainer Haselmann, and Paul Wachtel. (2016). "Pro-cyclical Capital Regulation and Lending.” Journal of Finance 71, 919-956.

Bentolila, Samuel, Marcel Jansen, Gabriel Jiménez, and Sonia Ruano. (2018) "When Credit Dries Up: Job Losses in the Great Recession.” Journal of the European Economic Association 16, 650-695.

Bräuning, Falk, and Victoria Ivashina. (2017) “Monetary Policy and Global Banking.” NBER Working Paper No. 23316.

Broner, Fernando, Tatiana Didier, Aitor Erce, and Sergio L. Schmukler. (2013) “Gross Capital Flows: Dynamics and Crises.” Journal of Monetary Economics 60, 113-133.

Brown, Martin, Karolin Kirschenmann, and Steven Ongena. (2013) "Bank Funding, Securitization, and Loan Terms: Evidence from Foreign Currency Lending." Journal of Money, Credit and Banking 46, 1313-1554.

Brown Martin, Steven Ongena, and Pinar Yeşin. (2011) "Foreign Currency Borrowing by Small Firms in the Transition Economies.” Journal of Financial Intermediation 20, 285-302

Bruno, Valentina, and Robert Hauswald. (2014) "The Real Effect of Foreign Banks.” Review of Finance 18, 1683-1716.

Burnside, Craig, Martin Eichenbaum, and Sergio Rebelo. (2004) "Government Guarantees and Self-Fulfilling Speculative Attacks.” Journal of Economic Theory 119, 31-63. 
Calderón, César, and Megumi Kubota. (2012) “Gross Inflows Gone Wild: Gross Capital inflows, Credit Booms and Crises.” The World Bank Policy Research, 6270, November.

Cameron, Colin A., and Douglas L. Miller. (2013) “A Practitioner’s Guide to Cluster-Robust Inference.” Journal of Human Resources 50, 317-372

Cetorelli, Nicola, and Linda S. Goldberg. (2011) “Global Banks and International Shock Transmission: Evidence from the Crisis.” IMF Economic Review 59, 41-76.

Chodorow-Reich, Gabriel. (2013) “The Employment Effect of Credit Market Disruptions: FirmLevel Evidence from the 2008-9 Financial Crisis.” Quarterly Journal of Economics October, 159.

Cingano, Federico, Francesco Manaresi, and Enrico Sette. (2016). "Does Credit Crunch Investments Down? New Evidence on the Real Effects of the Bank-Lending Channel.” Review of Financial Studies 29, 2737-2773.

Claessens, Stijn. (2017) “Global Banking: Recent Developments and Insights from Research.” Review of Finance 21, 1315-1555.

Claessens, Stijn, and Neeltje Van Horen. (2013) “Impact of Foreign Banks.” Journal of Financial Perspectives 1, 1-18.

Claessens, Stijn, and Neeltje Van Horen. (2014) "Foreign banks: Trends and impact." Journal of Money, Credit and Banking 46, 295-326.

Coffey, Niall, Warren B. Hrung, and Asani Sarkar. (2009) "Capital Constraints, Counterparty Risk, and Deviations from Covered Interest Rate Parity.” Federal Reserve Bank of New York Staff Reports no. 393.

De Fiore, Fiorella, and Harald Uhlig. (2015) “Corporate Debt Structure and the Financial Crisis.” Journal of Money, Credit and Banking 47, 1571-1598. 
De Haas, Ralph, and Neeltje Van Horen. (2012) “International Shock Transmission after the Lehman Brothers Collapse: Evidence from Syndicated Lending.” American Economic Review, Papers and Proceedings 102, 231-237.

Duchin, Ran, and Denis Sosyura. (2014) “Safer Ratios, Riskier Portfolios: Banks’ Response to Government Aid.” Journal of Financial Economics 113, 1-28.

Giannetti, Mariassunta, and Luc Laeven. (2012a) “The Flight Home Effect: Evidence from the Syndicated Loan Market during Financial Crises.” Journal of Financial Economics 104, 23-43.

Giannetti, Mariassunta, and Luc Laeven. (2012b) “Flight Home, Flight Abroad, and International Credit Cycles.” American Economic Review 102, 219-224.

Greene, William. (2010) “Testing Hypothesis about Interaction Terms in Non-Linear Models.” Economics Letters 107, 291-296.

Haltenhof, Samuel, Lee Seung Jung, and Viktors Stebunovs. (2014) “The Credit Crunch and Fall in Employment during the Great Recession.” Journal of Economic Dynamics and Control 43, 3157.

Haselmann, Rainer, and Paul Wachtel. (2011) “Foreign Banks in Syndicated Loan Markets.” Journal of Banking and Finance 35, 2679-2689.

Holmstrom, Bengt, and Jean Tirole. (1997) "Financial Intermediation, Loanable Funds, and the Real Sector.” Quarterly Journal of Economics 112, 663-691.

Ivashina, Victoria, and David Scharfstein. (2010) "Bank Lending During the Financial Crisis of 2008.” Journal of Financial Economics 97, 319-338.

Ivashina, Victoria, David S. Scharfstein, and Jeremy C. Stein. (2015) “Dollar Funding and the Lending Behavior of Global Banks.” Quarterly Journal of Economics 130, 1241-1281. 
Jeanne, Olivier. (2005) “Why Do Emerging Economies Borrow in Foreign Currency?” In Other People's Money, edited by Barry Eichengreen and Ricardo Hausmann, pp. 190-217. Chicago: University of Chicago Press.

Kashyap, Anil K., and Jeremy C. Stein. (2004) "Cyclical Implications of the Basel II Capital Standards.” Federal Reserve Bank of Chicago, Economic Perspectives 1Q/2004.

Keloharju, Matti, and Mervi Niskanen. (2001) "Why Do Firms Raise Foreign Currency Denominated Debt? Evidence from Finland.” European Financial Management 7, 481-496.

Landier, Augustin, David Sraer, and David Thesmar. (2015) “The Risk-Shifting Hypothesis: Evidence from Subprime Originations.” mimeo.

Mariathasan, Mike, and Ouarda Merrouche. (2012) "Recapitalization, Credit, and Liquidity." Economic Policy 27, 603-646.

McCauley, Robert N., Patrick McGuire, and Vladyslav Sushko. (2015) "Global Dollar Credit: Links to US Monetary Policy and Leverage.” BIS Working Paper No. 483.

Milesi-Ferretti, Gian-Maria, and Cédric Tille. (2011) “The Great Retrenchment: International Capital Flows during the Global Financial Crisis.” Economic Policy 66, 289-346.

Papke, Leslie E., Jeffrey M. Wooldridge. (1996) "Econometric Methods for Fractional Responses Variables with an Application to 401(K) Plan Participation Rates.” Journal of Applied Econometrics 11, 619-632.

Papke, Leslie E., Jeffrey M. Wooldridge. (2008) "Panel Data Methods for Fractional Response Variables with an Application to test Pass Rates.” Journal of Econometrics 145, 121-133.

Popov, Alexander, and Neeltje Van Horen. (2015) "Exporting Sovereign Stress: Evidence from Syndicated Bank Lending during the Euro Area Sovereign Debt Crisis.” Review of Finance 19, 1825-1866. 
Repullo, Rafael, and Javier Suarez. (2012) “The Procyclical Effects of Bank Capital Regulation.” Review of Financial Studies 26, 452-490.

Rose, Andrew K., and Tomasz Wieladek. (2014) "Financial Protectionism: The First Tests.” Journal of Finance 69, 2127-2149.

Schneider, Martin, and Aaron Tornell. (2004) "Balance Sheet Effects, Bailout Guarantees and Financial Crises.” Review of Economic Studies 71, 883-913.

\footnotetext{
${ }^{1}$ This increase cannot be attributed to a valuation effect: the euro appreciated against the dollar by about $20 \%$ during the period when the increase was strongest, i.e., Q2-2007 and Q3-2008.

${ }^{2}$ Throughout the paper we use the terms leveraged, non-investment grade, low-credit quality, and risky interchangeably. Non-investment grade firms in our sample have an average leverage ratio (or a ratio of long-term debt over total debt) of $19.5 \%$ against $5.7 \%$ for investment grade firms.

${ }^{3}$ This indicator is the net percentage of domestic banks surveyed by the European Central Bank (ECB) that report tightening in credit standards to large firms in the past 3 months.

${ }^{4}$ While the US officially adopted Basel II in 2007, the date of expected compliance was delayed to 2012. See Daryl Getter, US implementation of the Basel Capital Regulatory Framework, Congressional Research Report 7-5700, April 9 2014. On June 7, 2012, the Federal Banking Regulators announced the final rule for implementation of Basel II. First approvals for the use of Basel II capital rules were issued in February 2014.

${ }^{5}$ Relatedly, Duchin and Sosyura (2014) show that after receiving government support, US banks rebalance toward riskier assets and that this shift in risk occurs mostly within the same asset class and therefore remains undetected by regulatory capital ratios.

${ }^{6}$ We measure exposure to a weak domestic bank by a dummy indicating whether the last pre-crisis syndicate included the participation of a domestic bank that received public capital support, was forced into merger, or filed for bankruptcy between 2007 and 2010. The data are from Merrouche and Mariathasan (2012).
} 
${ }^{7}$ A related literature examines the role of banks with foreign ownership (see Claessens and Van Horen (2013) for a survey). After the financial crisis, foreign-owned banks reduced their lending more than domestically-owned banks. However, this decline was on average smaller than the decline in cross-border lending (see Claessens, 2017).

${ }^{8}$ For theoretical papers, see Aghion et al. (2004), Burnside et al. (2004), Jeanne (2005), or Schneider and Tornell (2004).

${ }^{9}$ Some of the recent literature focuses on the later period of the sovereign debt crisis, e.g., Acharya et al. (2018) or Popov and Van Horen (2015).

${ }^{10}$ Using IMF and BIS data for 2009, we find that the ratio of total outstanding syndicated credit over total bank claims on the EZ domestic non-financial private sector plus outstanding cross-border credit inflows is $32.6 \%$. Using ECB data instead, we find that the ratio of total outstanding syndicated credit over the stock of loans to non-financial firms is $32.2 \%$.

11 "Risky" indicates whether a loan is leveraged or high-yield, that is, made to relatively risky borrowers. Loan Pricing Corporation defines a leveraged loan as a syndicated loan that is rated $\mathrm{BB}+$ or lower or an unrated loan with an interest-rate spread larger than 150 basis points.

${ }^{12}$ Within a quarter, firms issue on average 2.6 loans mostly from the same syndicate and borrow on average from 4.6 banks. We do not however observe the contribution of each bank.

${ }^{13}$ Following the decision of BNP Paribas to suspend withdrawals from some of its hedged funds invested in US subprime mortgage backed securities due to the inability to mark these assets to markets.

${ }^{14}$ Although the method of calculation of this index is not harmonized across countries, that does not affect our analysis because our regressions include firms fixed effects. Three countries for which the index is not available, Greece, Finland, and Belgium, are excluded from the sample. From the same survey we also collected a measure of credit demand, the net percentage of banks reporting an increase in the demand for credit by large firms, for each EZ country.

${ }^{15}$ According to Coffrey, Hrung, and Sarkar (2009) arbitrageurs had limited capacity to shrink the basis due to the inability to raise capital quickly and/or heightened counterparty risk.

${ }^{16}$ Interest rates and exchange rates are downloaded from Reuters.

${ }^{17}$ Instead, before 2008, banks mention competition from foreign banks as a reason for loosening credit standards which would bias our estimates downward.

${ }^{18}$ All our results are also robust to the inclusion of country*year fixed effects.

${ }^{19}$ The net percentage of US (European) banks reporting an increase in the demand for credit. These measures are obtained from the Federal Reserve Board and the ECB websites, respectively.

${ }^{20}$ In the online Appendix Table A10 we also specify a linear probability model for the probability of borrowing from a foreign bank and use a dummy for the crisis period to measure credit tightening instead of CCI. When both the dependent variable and the explanatory variable are dummies, linear and non-linear models deliver similar results (see Angrist and Pischke, 2009). Our conclusions continue to hold with this alternative specification.

${ }^{21}$ We have followed Cameron and Miller (2013) in deciding at what level to cluster the standard errors. They recommend using "a conservative approach to avoid bias and use bigger and more aggregate clusters when possible, up to and including the point at which there is concern about having too few clusters". We tried also clustering by country only and the results are unchanged.

${ }^{22}$ The data come from Merrouche and Mariathasan (2012).

${ }^{23}$ The test p-value, not reported in the table, is 0.017 .

${ }^{24}$ These numbers are computed from Bankscope, where the origin of a bank is taken from Claessens and Van Horen (2014).

${ }^{25}$ For a detailed review of the difference in deposit insurance treatment between deposits in non-European and European banks see Azevedo and Bonfim, "Deposits Insurance and Cross-Border Banks”, ifo DICE Report I/ 2019 Spring Volume 17.

${ }^{26}$ The term non-European here is important because UK banks for example are non-EZ but European, their branches do have the obligation to participate in the deposit insurance scheme of the host country. Interestingly, in our results we find that among non-EZ banks, the shift away from euro lending is not significant for UK banks, which are nonEZ but European. 
${ }^{27}$ See Reuters 10.09.2013 “U.S. FDIC says foreign deposits not eligible for deposit insurance”.

${ }^{28}$ This is because one criterion for access is to be subject to the supervision of a European authority. See Guideline (EU) 2015/510 of the ECB of 19 December 2014 on the implementation of the Eurosystem monetary policy framework (ECB/2014/60), OJ L 91, 2.4.2015, p. 3, with Amending Guideline (EU) 2015/510 (ECB/2015/27), OJ L 282, 28.10.2015, p. 3.

${ }^{29}$ Bräuning and Ivashina (2017) also use the proportion of branches as an indicator of the ease of domestic deposits funding.

${ }^{30}$ If we estimate equation (2) on the full sample or the quarters when $C C I \leq 0$ all estimates are statistically insignificant. In line with our predictions disruptions in funding market cause a shift to dollar only in quarters when domestic banks restrict credit.

${ }^{31}$ For sake of brevity we just summarize our findings here which we report in the online Appendix Tables A6 to A8.

${ }^{32}$ Indeed, the marginal effect of a change in both interacted variables is not equal to the marginal effect of the interacted term,

${ }^{33}$ For sake of brevity we report the marginal effects for the non-interacted terms in the online Appendix in Table A9 as they were not significant statistically and economically.

${ }^{34}$ See online Appendix Tables A10 and A11.

${ }^{35}$ Available at https://www.bach.banque-france.fr/

${ }^{36}$ Although these data are available at firm level we used country-sector averages because of the very imperfect matching between SDC platinum and Amadeus.

${ }^{37}$ The data source for bond issuance is SDC platinum. We included only non-convertible bonds and excluded mortgage backed-securities, asset-backed securities, and preference shares which are listed as bonds.

${ }^{38}$ There are various mechanisms that can lead to a larger impact on more risky firms. E.g., Holmstrom and Tirole (1997), where a credit crunch removes all financing for the riskier firms. But if the credit crunch is for Home banks only, the riskier firms can turn to Foreign banks.

${ }^{39}$ The procyclical effect of Basel II capital standards has been widely discussed, both in theoretical models and in empirical analyses. E.g., see Behn et al. (2016), Kayshap and Stein (2004) or Repullo and Suarez (2012).

${ }^{40}$ Besides a simple substitution effect, there may have been additional factors pushing US banks towards more risky portfolios (e.g., low interest rates or government support). See Aramonte et al. (forthcoming), Duch and Sosyura (2014), or Landier et al. (2015).

${ }^{41}$ For example, Home firms have larger home currency deposits and easier access to Home central bank liquidity. 
Figure 1. Syndicated loan issuance denominated in US dollar

The sample includes all non-financial Eurozone borrowers.

Source: Thomson-Reuters Dealscan, European Central Bank

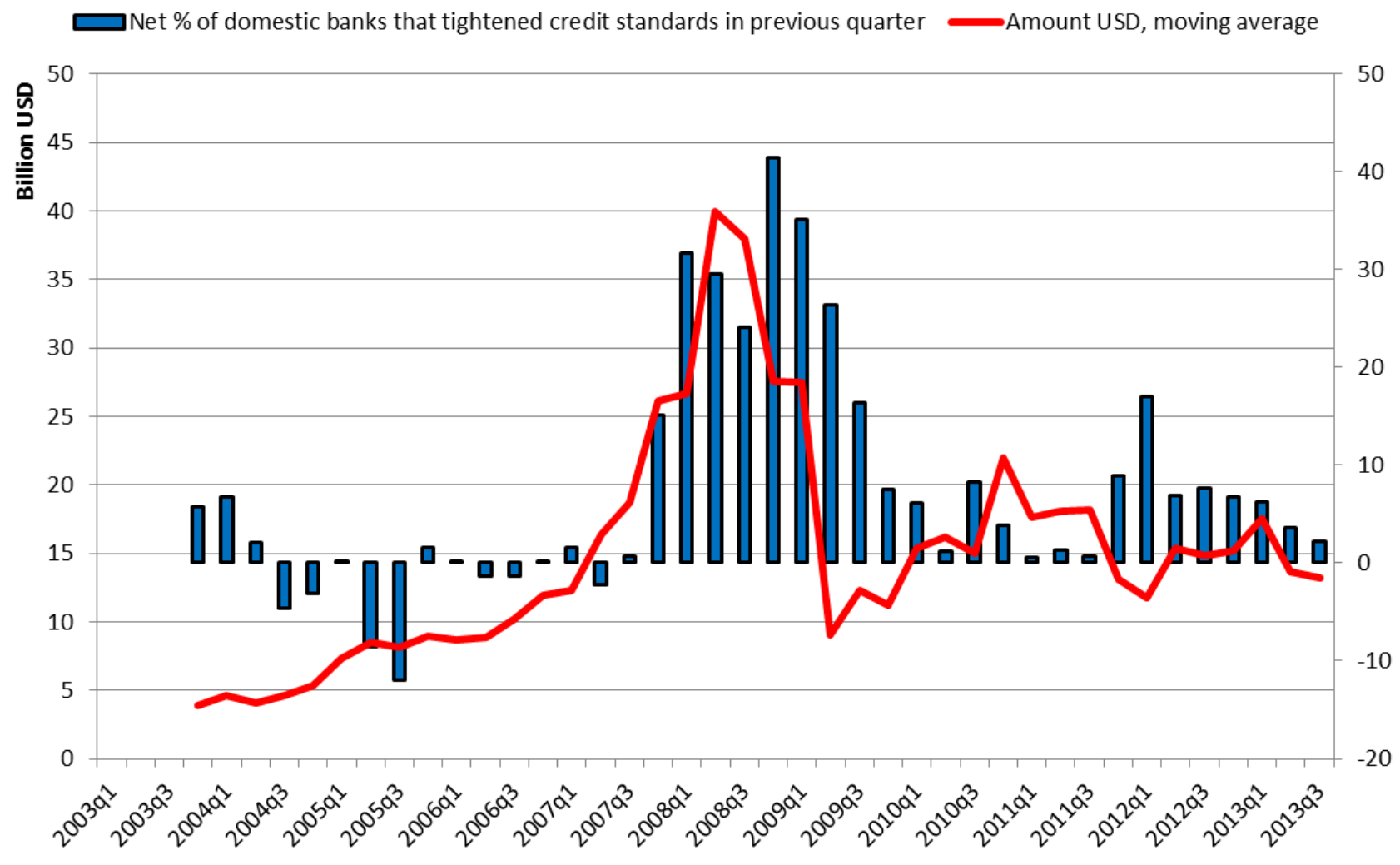


Figure 2. Percentage of syndicated loan issuance denominated in US dollars by borrower risk type

Risky borrowers are rated below investment grade. The sample includes all non-financial Eurozone borrowers.

Source: Thomson-Reuters Dealscan, authors' calculations

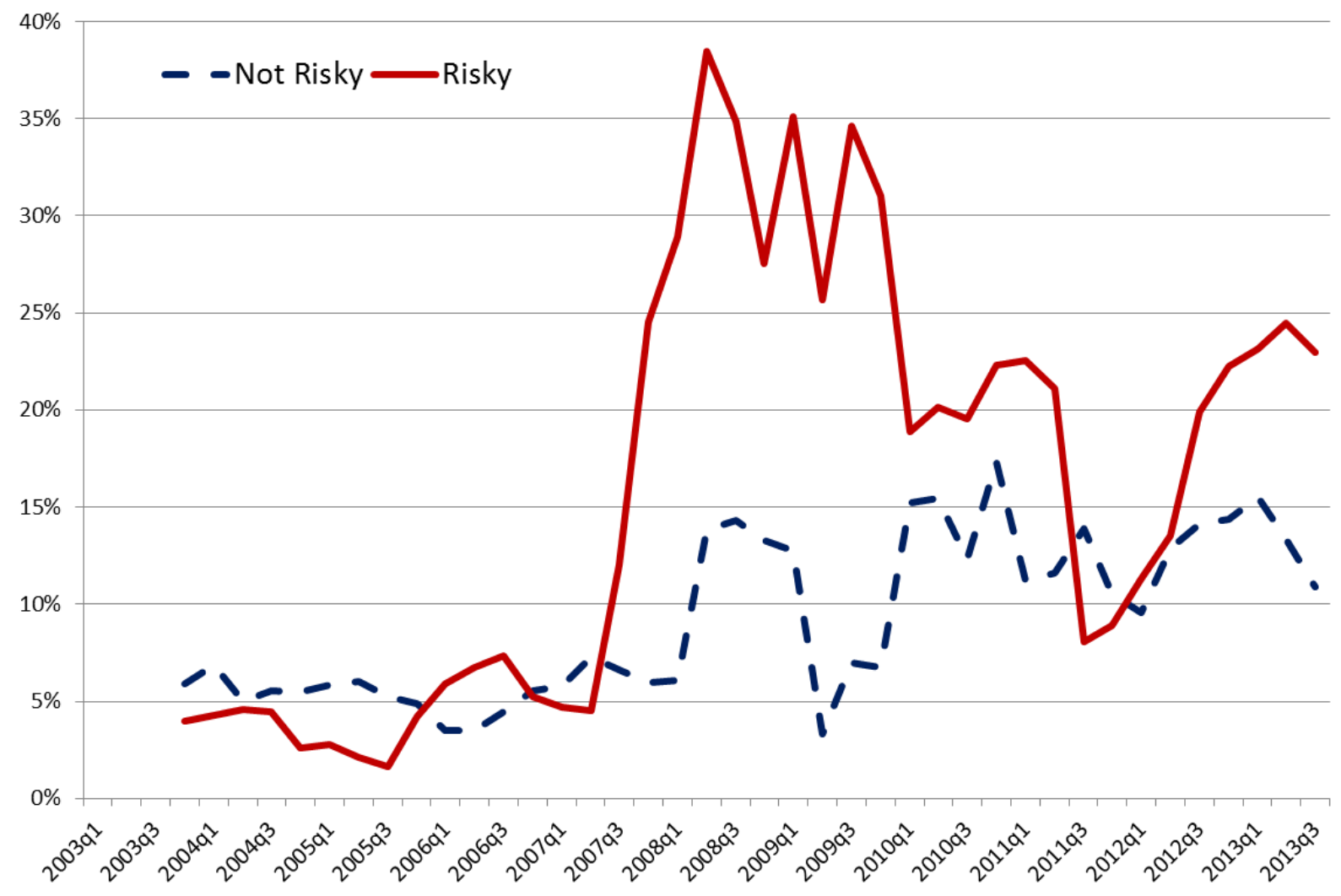




\section{Figure 3. Stress in the interbank market}

Source: Datastream

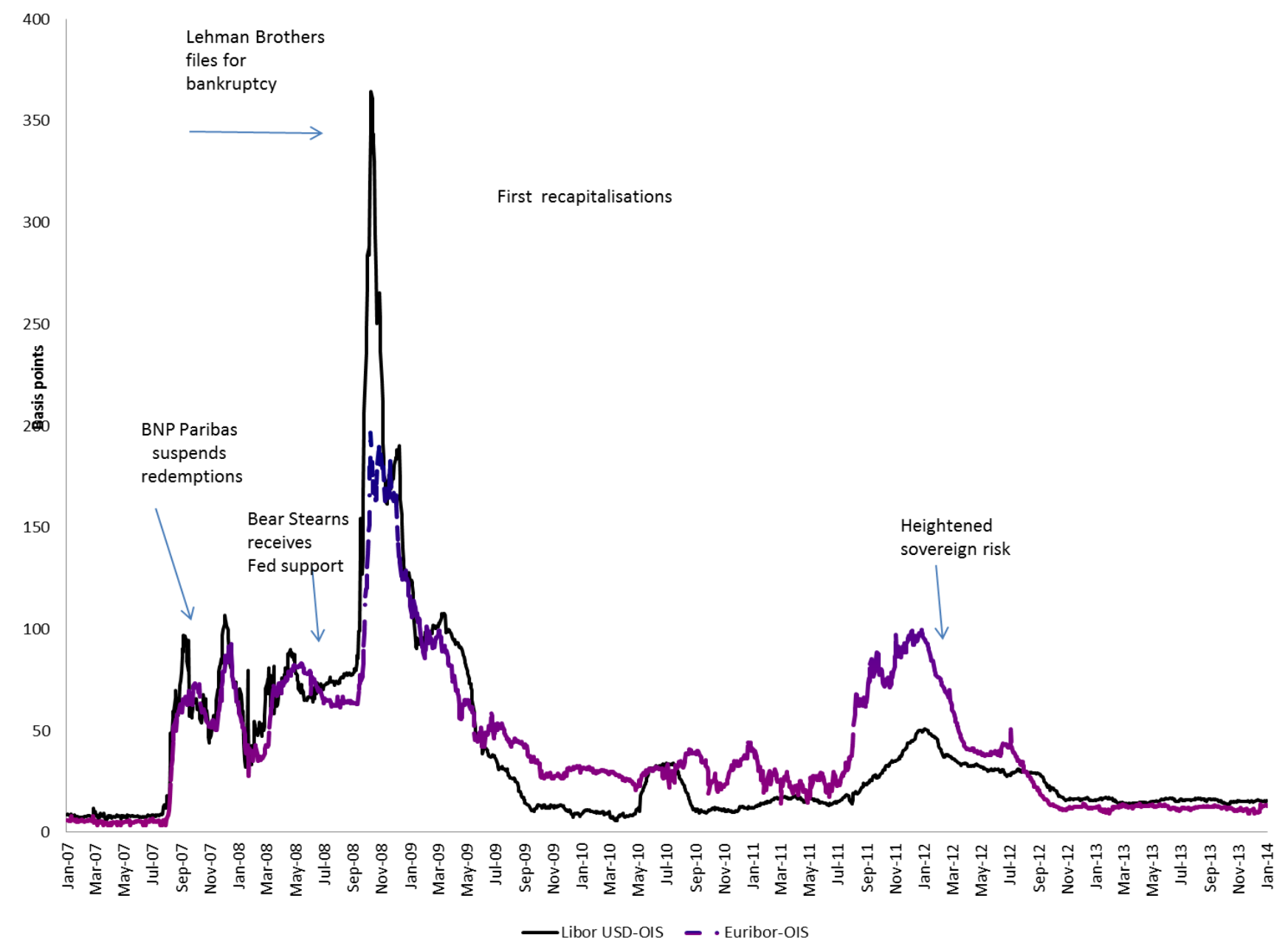


Figure 4. Deviation from covered interest parity measured by the Euro basis (basis points).

The Euro basis is constructed using 3 month daily euribor-OIS spread, 3 month daily dollar libor-OIS spread, and 3 month daily spot and forward rates downloaded from Datastream.

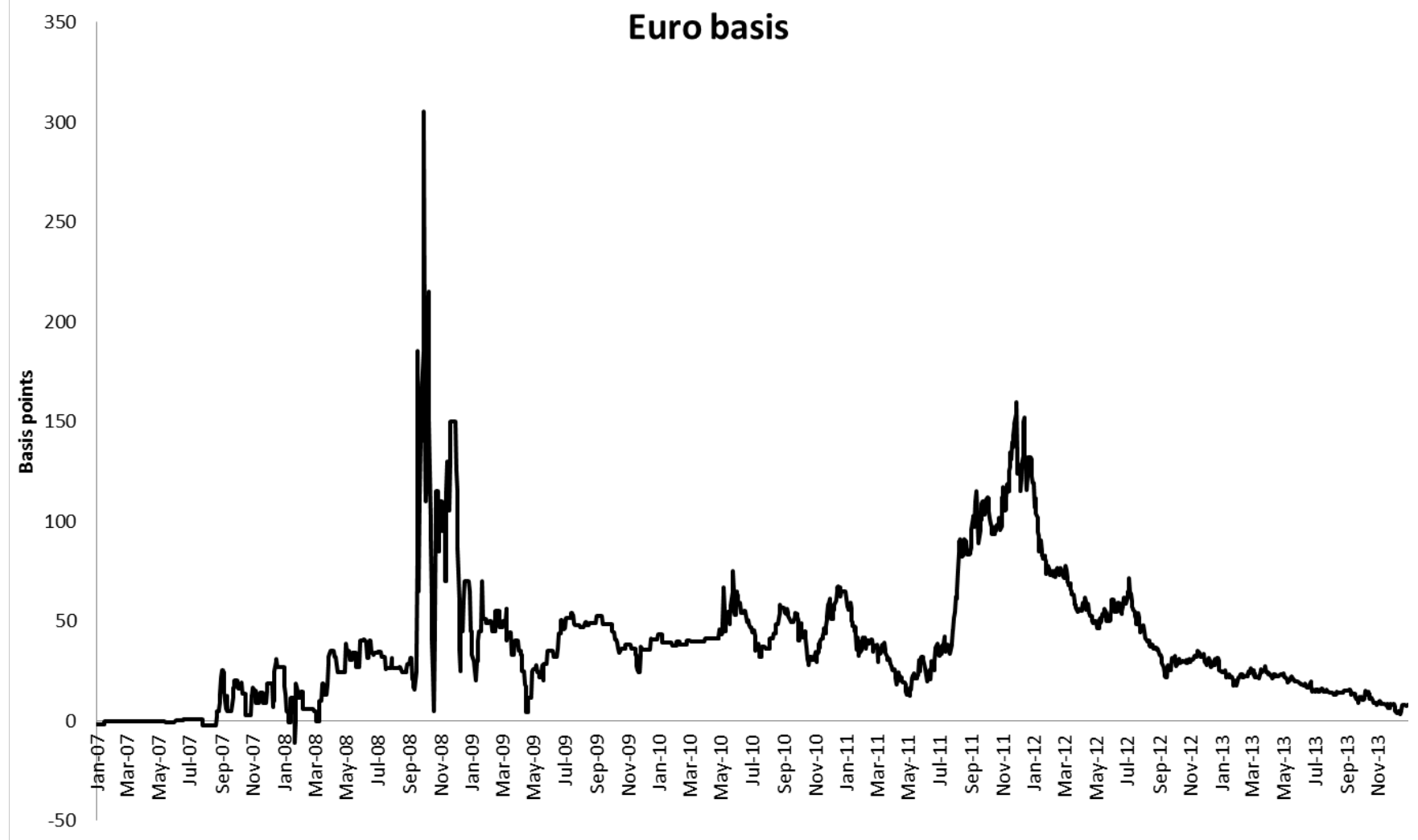


Figure 5. Relationship between credit standards and the predicted fraction of nonEurozone lenders from a fractional logit model for risky and not risky firms

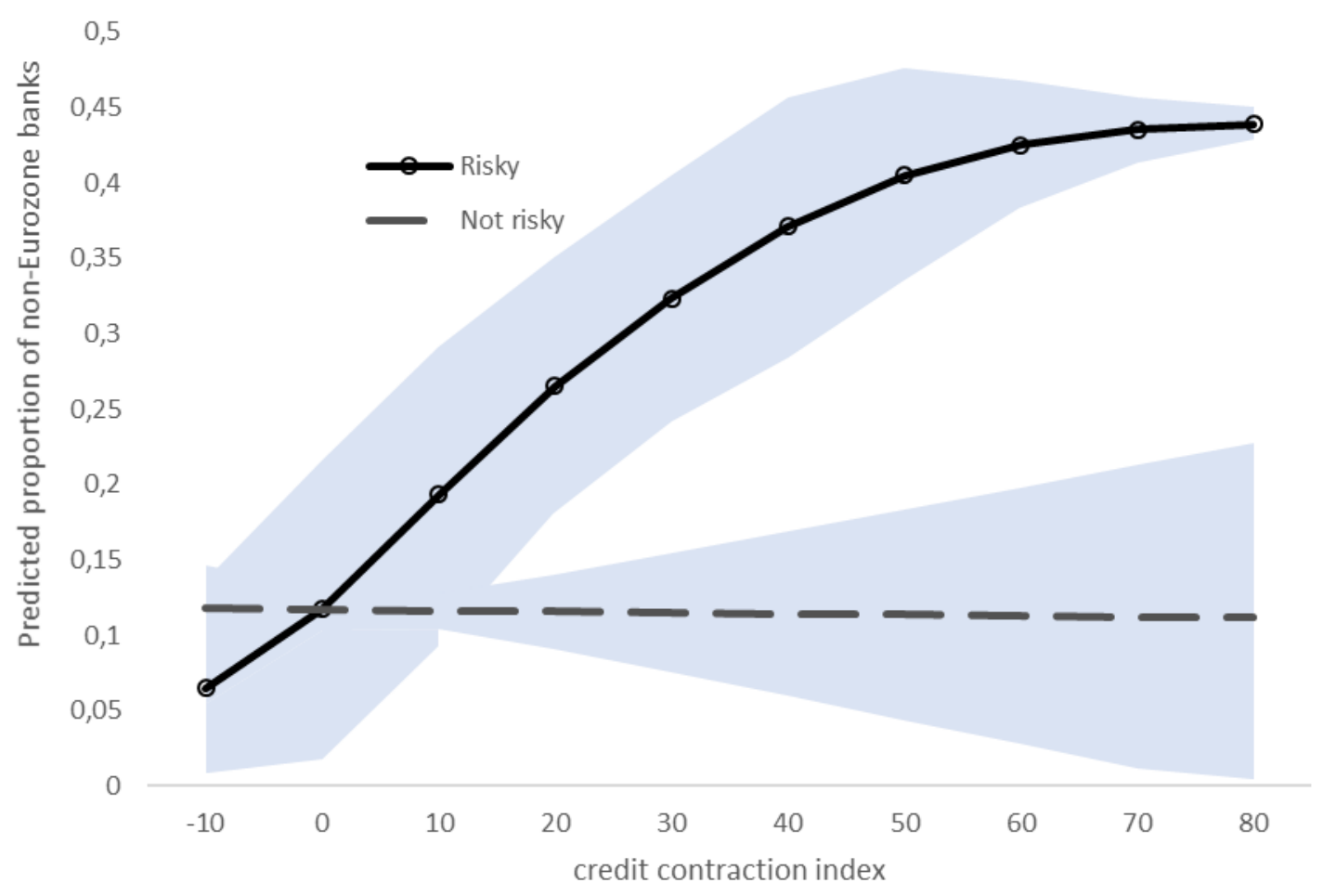

Note: The credit contraction index is the net $\%$ of banks that report tightening of credit standards in the past quarter from the ECB lending survey. Risky firms are firms rated below investment grade or not rated. The fractional logit model from which the predicted fraction of non-Eurozone lenders in a syndicate is derived includes the same set of control variables as in equation (1). The blue shaded area depicts the $95 \%$ confidence interval. 
Figure 6. Relationship between credit standards and the predicted probability of dollar borrowing from a logit model for risky and not risky firms

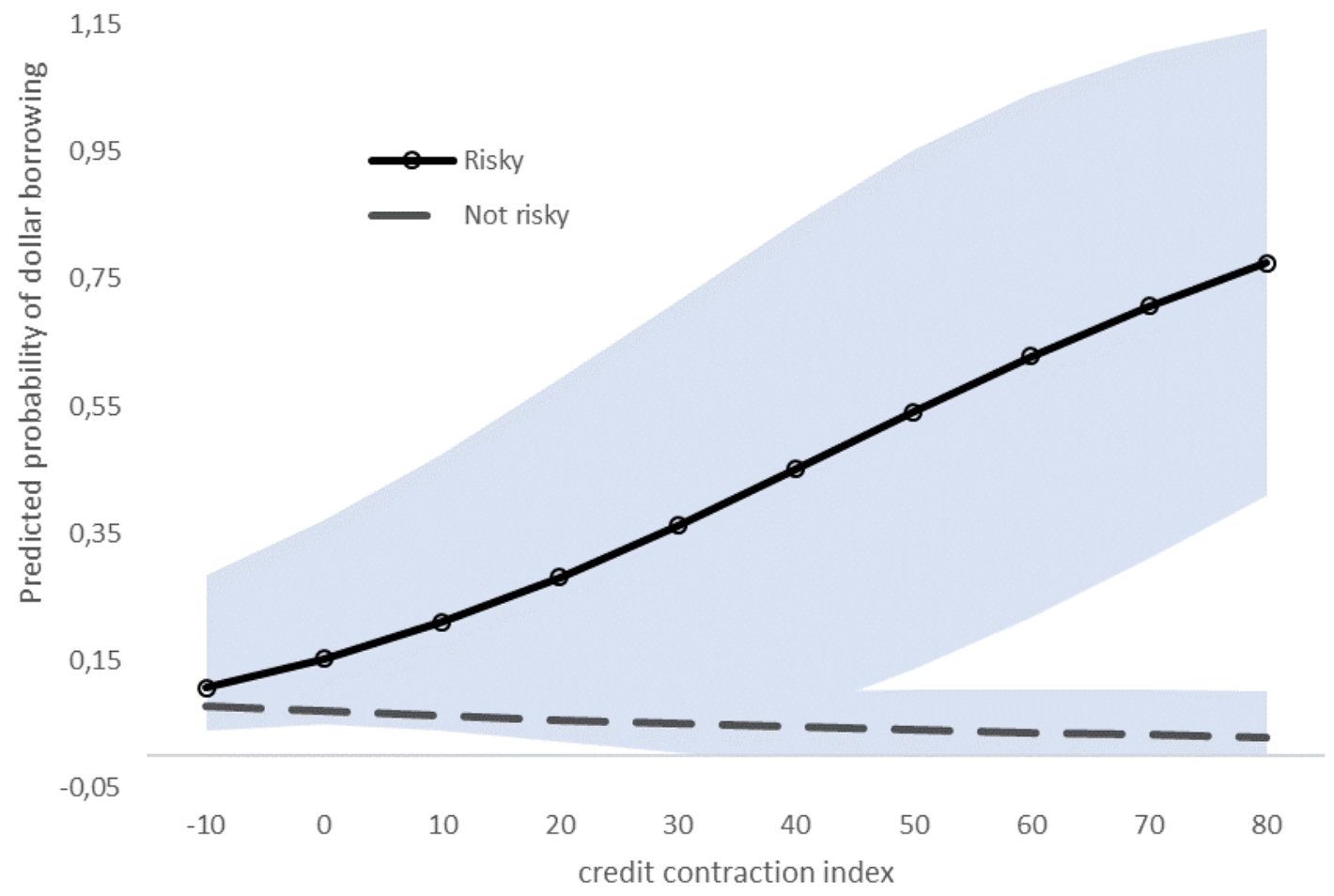

Note: The credit contraction index is the net $\%$ of banks that report tightening of credit standards in the past quarter from the ECB lending survey. Risky firms are firms rated below investment grade or not rated. The logit model from which the predicted probability of dollar borrowing is derived includes the same set of control variables as in equation (1). The blue shaded area depicts the $95 \%$ confidence interval. 
Figure 7. Relationship between the euro risk premium and the predicted probability of dollar borrowing from a logit model for risky and not risky firms

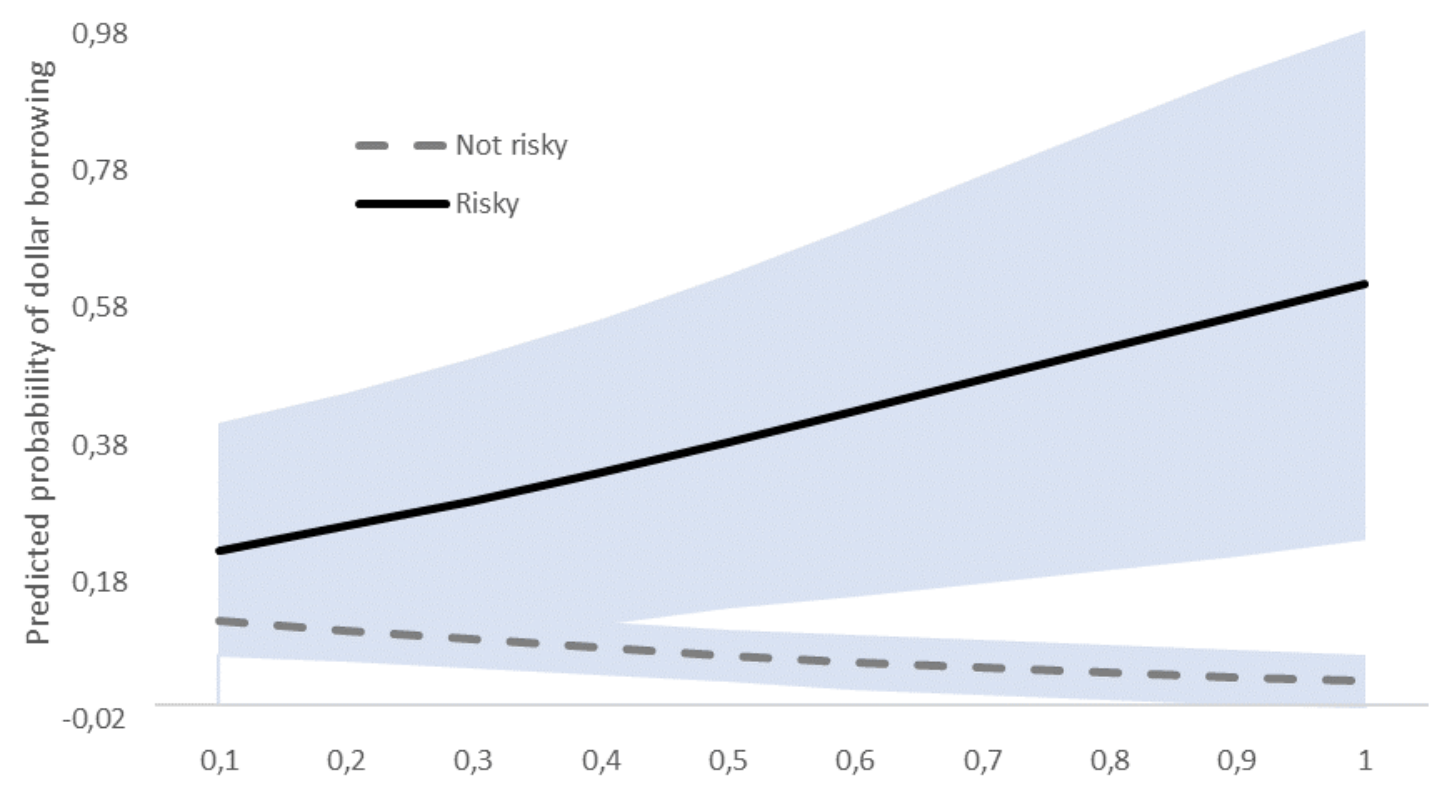

Euro risk premium

Note: Risky firms are firms rated below investment grade or not rated. The logit model from which the predicted probability of dollar borrowing is derived includes the same set of control variables as in equation (1). The blue shaded area depicts the $95 \%$ confidence interval. 


\section{Table 1. Sample composition by country}

This table reports the composition of our SDC Platinum sample by country. The sample period is 2004-Q1 to 2009Q4. Loans include both credit lines and term loans. In column I we report the number of firms with positive syndicated loan issuance by country over the sample period; in column II the number of issuers that have borrowed at least once from a non-Eurozone bank; and in column III the number of issuers that have borrowed at least once in US dollar. In columns IV-VI we report the number of firms that have borrowed at least twice and are therefore included in our regression sample including firm fixed effects.

\begin{tabular}{|c|c|c|c|c|c|c|}
\hline Country & $\begin{array}{c}\text { Number of } \\
\text { issuers }\end{array}$ & $\begin{array}{c}\text { Number of } \\
\text { issuers with a } \\
\text { non- } \\
\text { Eurozone } \\
\text { bank } \\
\text { relationship }\end{array}$ & $\begin{array}{l}\text { Number } \\
\text { of dollar } \\
\text { issuers }\end{array}$ & $\begin{array}{c}\text { Number } \\
\text { of } \\
\text { issuers }\end{array}$ & $\begin{array}{c}\text { Number of } \\
\text { issuers with a } \\
\text { non-Eurozone } \\
\text { bank } \\
\text { relationship }\end{array}$ & $\begin{array}{c}\text { Number } \\
\text { of dollar } \\
\text { issuers }\end{array}$ \\
\hline & I & II & III & IV & $\mathrm{V}$ & $\mathrm{VI}$ \\
\hline Austria & 27 & 15 & 2 & 9 & 8 & 1 \\
\hline Belgium & 90 & 44 & 10 & 23 & 20 & 3 \\
\hline Finland & 70 & 66 & 2 & 25 & 23 & 1 \\
\hline France & 856 & 337 & 59 & 215 & 154 & 23 \\
\hline Germany & 622 & 270 & 56 & 150 & 104 & 14 \\
\hline Greece & 77 & 45 & 21 & 17 & 12 & 8 \\
\hline Ireland & 72 & 39 & 18 & 15 & 9 & 3 \\
\hline Italy & 528 & 120 & 24 & 100 & 49 & 10 \\
\hline Luxembourg & 44 & 35 & 11 & 8 & 7 & 2 \\
\hline Netherlands & 296 & 190 & 54 & 84 & 69 & 26 \\
\hline Portugal & 160 & 29 & 11 & 14 & 3 & 2 \\
\hline Spain & 752 & 321 & 39 & 135 & 98 & 12 \\
\hline Total & 3594 & 1511 & 307 & 795 & 556 & 105 \\
\hline
\end{tabular}




\section{Table 2. Distribution of Eurozone syndicated loan activity by lender nationality}

This table reports market shares by lender nationality before and during the credit crunch based on amounts pro-rated by the number of participating banks. In order to abstract from changes in the population of firms tapping the market at different times, these shares are calculated on the sample of firms that have a positive demand for credit in both periods. We report total market shares, and separately market shares for the leveraged segment and the investment grade segment of the market. Finally, we report the percentage of lending that is the US dollars.

Q12004/Q22007

US banks

UK banks

Japenese banks

Other banks

All non-Eurozone banks

Eurozone banks

\begin{tabular}{cccc}
\hline $\begin{array}{c}\text { \% Total } \\
\text { lending }\end{array}$ & \% Risky & $\begin{array}{c}\text { \% Not } \\
\text { Risky }\end{array}$ & \% USD \\
\hline $17 \%$ & $24 \%$ & $16 \%$ & $11 \%$ \\
$9 \%$ & $8 \%$ & $9 \%$ & $10 \%$ \\
$3 \%$ & $1 \%$ & $3 \%$ & $8 \%$ \\
$12 \%$ & $15 \%$ & $12 \%$ & $8 \%$ \\
$41 \%$ & $\underline{\mathbf{4 9} \%}$ & $40 \%$ & $10 \%$ \\
$59 \%$ & $\underline{\mathbf{5 1 \%}}$ & $60 \%$ & $7 \%$ \\
\hline
\end{tabular}

Q3-

2007/Q4-

2009

US banks

UK banks

Japenese banks

Other banks

All non-Eurozone banks

Eurozone banks

\begin{tabular}{cccc}
\hline $\begin{array}{c}\text { \% Total } \\
\text { lending }\end{array}$ & \% Risky & $\begin{array}{c}\text { \% Not } \\
\text { Risky }\end{array}$ & \% USD \\
\hline $14 \%$ & $28 \%$ & $9 \%$ & $42 \%$ \\
$9 \%$ & $9 \%$ & $9 \%$ & $20 \%$ \\
$4 \%$ & $1 \%$ & $5 \%$ & $26 \%$ \\
$14 \%$ & $15 \%$ & $14 \%$ & $25 \%$ \\
$41 \%$ & $\underline{\mathbf{5 4 \%}}$ & $38 \%$ & $30 \%$ \\
$59 \%$ & $\underline{\mathbf{4 6 \%}}$ & $62 \%$ & $15 \%$ \\
\hline
\end{tabular}




\section{Table 3. Largest non-Eurozone banks participants in the Eurozone syndicated loans market}

This table reports the percentage of total lending by each listed bank to risky (non-investment grade) Eurozone borrowers, and the percentage of total lending denominated in US dollars. The numbers correspond to pro-rated figures.

\begin{tabular}{llll}
\hline Q1-2004/Q2-2007 & Q3-2007/Q4-2009 \\
\hline Risky & Dollar & Risky & Dollar \\
\hline
\end{tabular}

\section{UK and Swiss banks}

Barclays

Lloyds

Royal Bank of

Scotland

Crédit Suisse

\section{US banks}

BOA-Merrill Lynch

Citibank

Goldman Sachs

JP-Morgan

Morgan-Stanley

Japanese banks

Mitsubishi-UFJ

Namura-INC

Sumitomo

Mizuho

$\begin{array}{cccc}25 \% & 11 \% & 22 \% & 20 \% \\ 46 \% & 9 \% & 31 \% & 22 \% \\ & & & \\ 40 \% & 11 \% & 35 \% & 24 \% \\ 45 \% & 9 \% & 47 \% & 41 \%\end{array}$

$35 \% \quad 19 \% \quad 38 \% \quad 36 \%$

$20 \% \quad 21 \% \quad 32 \% \quad 31 \%$

$42 \% \quad 9 \% \quad 59 \% \quad 37 \%$

$44 \% \quad 25 \% \quad 54 \% \quad 44 \%$

$38 \% \quad 12 \% \quad 48 \% \quad 30 \%$

\begin{tabular}{cccc}
$7 \%$ & $10 \%$ & $6 \%$ & $16 \%$ \\
$70 \%$ & $8 \%$ & $71 \%$ & $36 \%$ \\
$18 \%$ & $7 \%$ & $10 \%$ & $16 \%$ \\
$36 \%$ & $11 \%$ & $13 \%$ & $19 \%$ \\
\hline
\end{tabular}




\section{Table 4. The domestic credit crunch and the shift to non-Eurozone banks}

The dependent variable is the proportion of non-Eurozone lead banks (arrangers) in the syndicate. Risky indicates whether a firm is rated non-investment grade. $C C I$ is the net percentage of Eurozone banks that tightened lending standards to large firms in the previous 3 months. Standard errors reported in parentheses are heteroskedasticity-robust and clustered by country*year. All columns include firm fixed effects, year-quarter fixed effects, and the Eurozone-US policy rate differential interacted Risky, the euro-dollar exchange rate change interacted with Risky, the Fed target rate interacted with Risky, the borrower home country credit demand index and its interaction with Risky, and the US credit demand index and its interaction with Risky. The data are quarterly for the period 2004-Q1 to 2009-Q4.

\begin{tabular}{|c|c|c|c|c|c|c|}
\hline & I & II & III & IV & V & VI \\
\hline & & & $\begin{array}{l}\text { Real purpose } \\
\text { loans }\end{array}$ & $\begin{array}{c}\text { Real purpose } \\
\text { loans, } \\
\text { including } \\
\text { loan purpose } \\
\text { fixed effects }\end{array}$ & $\begin{array}{l}\text { With US } \\
\text { bank } \\
\text { participation }\end{array}$ & Weak bank \\
\hline Risky & $\begin{array}{l}-1.553 \\
(2.984)\end{array}$ & $\begin{array}{l}-2.115 \\
(2.905)\end{array}$ & $\begin{array}{l}-7.679 \\
(6.026)\end{array}$ & $\begin{array}{r}-10.531 \\
(6.081)^{*}\end{array}$ & $\begin{array}{l}-0.201 \\
(3.526)\end{array}$ & $\begin{array}{r}0.551 \\
(6.783)\end{array}$ \\
\hline CCI & $\begin{array}{r}-0.039 \\
(0.041)\end{array}$ & $\begin{array}{l}-0.069 \\
(0.043)\end{array}$ & $\begin{array}{l}-0.027 \\
(0.112)\end{array}$ & $\begin{array}{r}0.002 \\
(0.105)\end{array}$ & $\begin{array}{c}0.002 \\
(0.054)\end{array}$ & $\begin{array}{c}-0.295 \\
(0.111)^{* *}\end{array}$ \\
\hline CCI*Risky & & $\begin{array}{r}0.106 \\
(0.094)\end{array}$ & $\begin{array}{c}0.523 \\
(0.151)^{* * *}\end{array}$ & $\begin{array}{c}0.495 \\
(0.145)^{* * *}\end{array}$ & $\begin{array}{c}0.184 \\
(0.086)^{* *}\end{array}$ & $\begin{array}{c}0.373 \\
(0.149)^{* *}\end{array}$ \\
\hline$R^{2}$ & 0.03 & 0.03 & 0.12 & 0.15 & 0.06 & 0.04 \\
\hline$N$ & 1839 & 1839 & 700 & 700 & 1229 & 752 \\
\hline
\end{tabular}




\section{Table 5. The domestic credit crunch and the shift to US dollar}

The sample period is Q1-2004 to Q4-2009 and the variables are as defined in Table 4. Standard errors are heteroskedasticity-robust and clustered by country*year. All columns include firm fixed effects, year-quarter fixed effects, and the Eurozone-US policy rate differential interacted Risky, the eurodollar exchange rate change interacted with Risky, the Fed target interacted with Risky, the borrower home country credit demand index and its interaction with Risky, and the US credit demand index and its interaction with Risky.

\begin{tabular}{|c|c|c|c|c|c|c|}
\hline & I & II & III & IV & V & VI \\
\hline & $\begin{array}{l}\text { Real purpose } \\
\text { loans }\end{array}$ & \multicolumn{2}{|c|}{ With US bank participation } & $\begin{array}{c}\text { Real } \\
\text { purpose } \\
\text { loans }\end{array}$ & \multicolumn{2}{|c|}{ With US bank participation } \\
\hline $\begin{array}{c}\text { Dependent } \\
\text { variable }\end{array}$ & \multicolumn{3}{|c|}{ \% dollar borrowing } & \multicolumn{3}{|c|}{ Dummy for dollar borrowing } \\
\hline Risky & $\begin{array}{l}-4.767 \\
(3.883)\end{array}$ & $\begin{array}{l}1.939 \\
(4.879)\end{array}$ & $\begin{array}{r}0.870 \\
(5.356)\end{array}$ & $\begin{array}{r}0.016 \\
(0.041)\end{array}$ & $\begin{array}{c}0.022 \\
(0.040)\end{array}$ & $\begin{array}{r}0.006 \\
(0.047)\end{array}$ \\
\hline CCI & $\begin{array}{l}0.037 \\
(0.112)\end{array}$ & $\begin{array}{r}-0.142 \\
(0.189)\end{array}$ & $\begin{array}{r}-0.142 \\
(0.173)\end{array}$ & $\begin{array}{r}0.001 \\
(0.001)\end{array}$ & $\begin{array}{l}-0.000 \\
(0.002)\end{array}$ & $\begin{array}{l}-0.000 \\
(0.002)\end{array}$ \\
\hline CCI*Risky & $\begin{array}{l}0.206 \\
(0.142)\end{array}$ & $\begin{array}{c}0.480 \\
(0.198)^{* *}\end{array}$ & $\begin{array}{c}0.427 \\
(0.190)^{* *}\end{array}$ & $\begin{array}{r}0.003 \\
(0.002)\end{array}$ & $\begin{array}{c}0.004 \\
(0.002)^{*}\end{array}$ & $\begin{array}{l}0.004 \\
(0.002)^{* *}\end{array}$ \\
\hline $\begin{array}{l}\text { Loan } \\
\text { purpose FE }\end{array}$ & no & no & yes & no & no & yes \\
\hline$R^{2}$ & 0.11 & 0.11 & 0.14 & 0.11 & 0.09 & 0.15 \\
\hline$N$ & 700 & 470 & 470 & 700 & 470 & 470 \\
\hline
\end{tabular}

${ }^{*} p<0.1 ;{ }^{* *} p<0.05 ;{ }^{* * *} p<0.001$ 


\section{Table 6. The shift to non-Eurozone banks: additional firm characteristics}

This tables reports results with additional firms' characteristics for a sample of firms that could be matched with Amadeus. Descriptive statistics are reported in Table A2 of the online Appendix. Collateral is tangible assets over total assets, leverage is long term debt over total assets. All other variables are as defined in Table 4. Standard errors reported in parentheses are heteroskedasticity-robust and clustered by country*year.

\begin{tabular}{|c|c|c|c|c|c|c|}
\hline $\begin{array}{l}\text { Dependent } \\
\text { variables }\end{array}$ & $\begin{array}{c}\text { I } \\
\text { \% non- } \\
\text { Eurozone } \\
\text { banks }\end{array}$ & $\begin{array}{c}\text { II } \\
\% \\
\text { dollar } \\
\text { borrowing }\end{array}$ & $\begin{array}{c}\text { III } \\
\text { \% non- } \\
\text { Eurozone } \\
\text { banks }\end{array}$ & $\begin{array}{c}\text { IV } \\
\text { \% dollar } \\
\text { borrowing }\end{array}$ & $\begin{array}{c}\mathrm{V} \\
\text { \% non- } \\
\text { Eurozone } \\
\text { banks }\end{array}$ & $\begin{array}{c}\text { VI } \\
\text { \% dollar } \\
\text { borrowing }\end{array}$ \\
\hline Risky & $\begin{array}{c}-10.531 \\
(6.081)^{*}\end{array}$ & $\begin{array}{r}-6.191 \\
(3.782)\end{array}$ & $\begin{array}{c}-26.259 \\
(7.393)^{* * *}\end{array}$ & $\begin{array}{c}-14.727 \\
(9.469)\end{array}$ & & \\
\hline CCI & $\begin{array}{r}0.002 \\
(0.105)\end{array}$ & $\begin{array}{r}0.051 \\
(0.110)\end{array}$ & $\begin{array}{r}0.107 \\
(0.326)\end{array}$ & $\begin{array}{r}0.295 \\
(0.884)\end{array}$ & & \\
\hline CCI*Risky & $\begin{array}{r}0.495 \\
(0.145)^{* * *}\end{array}$ & $\begin{array}{r}0.192 \\
(0.143)\end{array}$ & $\begin{array}{c}0.454 \\
(0.264)^{*}\end{array}$ & $\begin{array}{c}0.602 \\
(0.335)^{*}\end{array}$ & & \\
\hline Leverage & & & & & $\begin{array}{r}-6.000 \\
(12.082)\end{array}$ & $\begin{array}{l}-3.776 \\
(8.456)\end{array}$ \\
\hline CCI*Leverage & & & & & $\begin{array}{r}-0.127 \\
(0.701)\end{array}$ & $\begin{array}{c}0.821 \\
(0.424)^{*}\end{array}$ \\
\hline Log assets & & & $\begin{array}{c}-3.986 \\
(1.574)^{* *}\end{array}$ & $\begin{array}{l}-1.123 \\
(2.123)\end{array}$ & $\begin{array}{l}-2.326 \\
(1.487)\end{array}$ & $\begin{array}{l}-0.473 \\
(2.547)\end{array}$ \\
\hline CCI*Log assets & & & $\begin{array}{c}-0.063 \\
(0.041)\end{array}$ & $\begin{array}{l}-0.070 \\
(0.085)\end{array}$ & $\begin{array}{r}-0.039 \\
(0.048)\end{array}$ & $\begin{array}{r}0.044 \\
(0.055)\end{array}$ \\
\hline ROA & & & $\begin{array}{c}-0.052 \\
(0.069)\end{array}$ & $\begin{array}{r}0.299 \\
(0.191)\end{array}$ & $\begin{array}{r}-0.059 \\
(0.094)\end{array}$ & $\begin{array}{r}0.330 \\
(0.200)\end{array}$ \\
\hline CCI*ROA & & & $\begin{array}{l}-0.001 \\
(0.004)\end{array}$ & $\begin{array}{c}-0.031 \\
(0.010)^{* * *}\end{array}$ & $\begin{array}{r}0.000 \\
(0.003)\end{array}$ & $\begin{array}{c}-0.024 \\
(0.011)^{* *}\end{array}$ \\
\hline Log cash & & & $\begin{array}{r}1.178 \\
(0.730)\end{array}$ & $\begin{array}{c}0.602 \\
(1.526)\end{array}$ & $\begin{array}{r}1.119 \\
(0.700)\end{array}$ & $\begin{array}{c}1.640 \\
(1.285)\end{array}$ \\
\hline CCI*Log cash & & & $\begin{array}{c}0.083 \\
(0.038)^{* *}\end{array}$ & $\begin{array}{r}0.073 \\
(0.065)\end{array}$ & $\begin{array}{r}0.055 \\
(0.045)\end{array}$ & $\begin{array}{l}-0.024 \\
(0.033)\end{array}$ \\
\hline Collateral & & & $\begin{array}{r}7.964 \\
(7.670)\end{array}$ & $\begin{array}{c}-21.724 \\
(16.473)\end{array}$ & $\begin{array}{r}6.342 \\
(8.084)\end{array}$ & $\begin{array}{c}-28.949 \\
(21.261)\end{array}$ \\
\hline CCI*collateral & & & $\begin{array}{c}-0.425 \\
(0.250)^{*}\end{array}$ & $\begin{array}{c}-0.259 \\
(0.341)\end{array}$ & $\begin{array}{r}-0.348 \\
(0.324)\end{array}$ & $\begin{array}{c}-0.868 \\
(0.316)^{* * *}\end{array}$ \\
\hline CCI*Listed & & & $\begin{array}{c}-0.387 \\
(0.162)^{* *}\end{array}$ & $\begin{array}{r}0.084 \\
(0.172)\end{array}$ & $\begin{array}{r}-0.387 \\
(0.192)^{* *}\end{array}$ & $\begin{array}{l}-0.127 \\
(0.150)\end{array}$ \\
\hline$R^{2}$ & 0.15 & 0.11 & 0.24 & 0.32 & 0.21 & 0.34 \\
\hline$N$ & 873 & 873 & 873 & 873 & 837 & 837 \\
\hline
\end{tabular}

${ }^{*} p<0.1 ; * * p<0.05 ; * * * p<0.01$ 


\section{Table 7. Robustness to controlling for other bank characteristics}

In columns I and II the dependent variable is the percentage of a given bank lending to risky firms. In columns III to V it is the percentage of a bank lending in dollar. In column V we focus on lending to risky borrowers. The sample covers 51 banks that have a significant participation in the European syndicated loans market. Crisis is a post Q2-2007 dummy. Bank characteristics are lagged one year. Descriptive statistics are reported in Table A3 of the online Appendix. Bank and year-quarter fixed effects are included. Standard errors are clustered by bank.

\begin{tabular}{|c|c|c|c|c|c|}
\hline & I & II & III & IV & $\mathrm{V}$ \\
\hline Crisis*Non-Eurozone bank dummy & $\begin{array}{c}9.749 \\
(4.128)^{* *}\end{array}$ & & $\begin{array}{c}11.616 \\
(2.963)^{* * *}\end{array}$ & & $\begin{array}{c}20.199 \\
(4.659) * * *\end{array}$ \\
\hline Tier 1 capital ratio & $\begin{array}{c}1.270 \\
(1.636)\end{array}$ & $\begin{array}{c}1.459 \\
(1.610)\end{array}$ & $\begin{array}{l}-0.523 \\
(0.950)\end{array}$ & $\begin{array}{l}-0.610 \\
(0.920)\end{array}$ & $\begin{array}{c}-2.634 \\
(1.326)^{* *}\end{array}$ \\
\hline Crisis*Tier 1 capital ratio & $\begin{array}{l}-2.561 \\
(1.353)^{*}\end{array}$ & $\begin{array}{l}-2.898 \\
(1.383)^{* *}\end{array}$ & $\begin{array}{c}1.052 \\
(0.970)\end{array}$ & $\begin{array}{c}1.218 \\
(0.902)\end{array}$ & $\begin{array}{c}3.414 \\
(1.144)^{* * *}\end{array}$ \\
\hline Loans over deposits & $\begin{array}{l}-0.001 \\
(0.029)\end{array}$ & $\begin{array}{l}-0.005 \\
(0.029)\end{array}$ & $\begin{array}{c}0.005 \\
(0.010)\end{array}$ & $\begin{array}{c}0.006 \\
(0.010)\end{array}$ & $\begin{array}{c}0.021 \\
(0.015)\end{array}$ \\
\hline Crisis*Loans over deposits & $\begin{array}{c}0.061 \\
(0.028)^{* *}\end{array}$ & $\begin{array}{c}0.067 \\
(0.027)^{* *}\end{array}$ & $\begin{array}{l}-0.010 \\
(0.011)\end{array}$ & $\begin{array}{l}-0.011 \\
(0.011)\end{array}$ & $\begin{array}{l}-0.026 \\
(0.017)\end{array}$ \\
\hline Loans over long term funding & $\begin{array}{l}-0.748 \\
(0.406) *\end{array}$ & $\begin{array}{l}-0.579 \\
(0.413)\end{array}$ & $\begin{array}{c}0.157 \\
(0.315)\end{array}$ & $\begin{array}{c}0.225 \\
(0.316)\end{array}$ & $\begin{array}{l}-0.033 \\
(0.344)\end{array}$ \\
\hline Crisis*Loans over long term funding & $\begin{array}{l}-0.242 \\
(0.281)\end{array}$ & $\begin{array}{c}0.170 \\
(0.311)\end{array}$ & $\begin{array}{l}-0.268 \\
(0.322)\end{array}$ & $\begin{array}{l}-0.203 \\
(0.350)\end{array}$ & $\begin{array}{l}-0.530 \\
(0.442)\end{array}$ \\
\hline Impaired loans over loans & $\begin{array}{l}-0.039 \\
(0.050)\end{array}$ & $\begin{array}{l}-0.005 \\
(0.052)\end{array}$ & $\begin{array}{l}-0.022 \\
(0.033)\end{array}$ & $\begin{array}{l}-0.015 \\
(0.033)\end{array}$ & $\begin{array}{l}-0.019 \\
(0.038)\end{array}$ \\
\hline Crisis*Impaired loans over loans & $\begin{array}{l}-0.041 \\
(0.104)\end{array}$ & $\begin{array}{l}-0.100 \\
(0.109)\end{array}$ & $\begin{array}{l}-0.058 \\
(0.074)\end{array}$ & $\begin{array}{l}-0.056 \\
(0.079)\end{array}$ & $\begin{array}{l}-0.058 \\
(0.074)\end{array}$ \\
\hline Log total assets & $\begin{array}{c}1.528 \\
(0.631)^{* *}\end{array}$ & $\begin{array}{l}1.566 \\
(0.643)^{* *}\end{array}$ & $\begin{array}{l}-0.419 \\
(0.483)\end{array}$ & $\begin{array}{l}-0.286 \\
(0.477)\end{array}$ & $\begin{array}{l}-0.098 \\
(0.683)\end{array}$ \\
\hline Crisis*Log total assets & $\begin{array}{l}-0.713 \\
(0.732)\end{array}$ & $\begin{array}{l}-0.930 \\
(0.744)\end{array}$ & $\begin{array}{c}1.099 \\
(0.505)^{* *}\end{array}$ & $\begin{array}{c}0.887 \\
(0.506)^{*}\end{array}$ & $\begin{array}{c}1.108 \\
(0.746)\end{array}$ \\
\hline Crisis*US bank dummy & & $\begin{array}{l}15.528 \\
(6.580)^{* *}\end{array}$ & & $\begin{array}{c}21.414 \\
(5.363)^{* * *}\end{array}$ & \\
\hline Crisis*UK bank dummy & & $\begin{array}{c}3.731 \\
(5.228)\end{array}$ & & $\begin{array}{c}6.205 \\
(3.493)^{*}\end{array}$ & \\
\hline Crisis*Japenese bank dummy & & $\begin{array}{l}-3.857 \\
(6.389)\end{array}$ & & $\begin{array}{l}10.047 \\
(5.940)^{*}\end{array}$ & \\
\hline Crisis*Other banks & & $\begin{array}{l}21.310 \\
(7.920)^{* * *}\end{array}$ & & $\begin{array}{c}7.718 \\
(6.227)\end{array}$ & \\
\hline$R^{2}$ & 0.18 & 0.19 & 0.25 & 0.26 & 0.30 \\
\hline$N$ & 742 & 742 & 742 & 742 & 637 \\
\hline
\end{tabular}

${ }^{*} p<0.1 ; * * p<0.05 ; * * * p<0.01$ 


\section{Table 8. Shift to dollar: Heterogeneity across non-Eurozone banks}

The dependent variable is the percentage of a given bank lending denominated in dollar. The sample covers non-Eurozone banks that have a significant participation in the European syndicated loans market. Crisis is a post Q2-2007 dummy. \% Subsidiaries equals (subsidiaries/(subsidiaries+branches))*100. The Bank characteristics are lagged one year. Bank and year-quarter fixed effects are included. Standard errors are clustered by bank.

\begin{tabular}{|c|c|c|}
\hline & I & II \\
\hline & Total lending & $\begin{array}{l}\text { Lending to } \\
\text { risky firms }\end{array}$ \\
\hline Crisis*\% Subsidiaries & $\begin{array}{l}-46.011 \\
(20.240) * *\end{array}$ & $\begin{array}{l}-57.184 \\
(28.914) * *\end{array}$ \\
\hline Tier 1 capital ratio & $\begin{array}{l}-0.429 \\
(2.176)\end{array}$ & $\begin{array}{l}-1.842 \\
(2.957)\end{array}$ \\
\hline Crisis*Tier 1 capital ratio & $\begin{array}{c}0.112 \\
(2.170)\end{array}$ & $\begin{array}{c}5.248 \\
(2.964) *\end{array}$ \\
\hline Loans over deposits & $\begin{array}{l}-0.158 \\
(0.174)\end{array}$ & $\begin{array}{l}-0.295 \\
(0.288)\end{array}$ \\
\hline Crisis*Loans over deposits & $\begin{array}{c}0.061 \\
(0.107)\end{array}$ & $\begin{array}{l}-0.015 \\
(0.188)\end{array}$ \\
\hline Loans over long term funding & $\begin{array}{c}1.239 \\
(1.018)\end{array}$ & $\begin{array}{l}-0.110 \\
(1.134)\end{array}$ \\
\hline Crisis*Loans over long term funding & $\begin{array}{l}-0.835 \\
(0.497)^{*}\end{array}$ & $\begin{array}{l}-0.660 \\
(0.556)\end{array}$ \\
\hline Impaired loans over loans & $\begin{array}{l}-0.034 \\
(0.064)\end{array}$ & $\begin{array}{l}-0.070 \\
(0.076)\end{array}$ \\
\hline Crisis*Impaired loans over loans & $\begin{array}{l}-0.195 \\
(0.206)\end{array}$ & $\begin{array}{l}-0.053 \\
(0.222)\end{array}$ \\
\hline Log total assets & $\begin{array}{l}-0.637 \\
(1.042)\end{array}$ & $\begin{array}{l}-0.484 \\
(1.802)\end{array}$ \\
\hline Crisis*Log total assets & $\begin{array}{c}1.819 \\
(1.316)\end{array}$ & $\begin{array}{c}2.239 \\
(2.243)\end{array}$ \\
\hline$R^{2}$ & 0.41 & 0.54 \\
\hline$N$ & 275 & 227 \\
\hline
\end{tabular}




\section{Table 9. Alternative hypothesis: heightened search for yield in credit from non-Eurozone banks}

The dependent variable is the cost of debt measured by the all-in-drawn spread to benchmark. The sample period is Q1-2004 to Q4-2009 and the variables are as defined in Table 4. All columns include firm fixed effects and year-quarter fixed effects, and control for issue type fixed effects, issue size, maturity in months, and issue purpose. All columns also include the Eurozone-US policy rate differential interacted Risky, The eurodollar exchange rate change interacted with Risky, the Fed target interacted with Risky, the borrower home country credit demand index and its interaction with Risky, and the US credit demand index and its interaction with Risky. We exclude firm-quarters with zero debt issuance. Standard errors reported in parentheses are heteroskedasticity-robust and clustered by country*year.

\begin{tabular}{lcc}
\hline & I & II \\
\hline & $\begin{array}{c}\text { Loans from } \\
\text { non-Eurozone } \\
\text { banks }\end{array}$ & $\begin{array}{c}\text { Loans from } \\
\text { Eurozone banks }\end{array}$ \\
\hline Risky & 1.050 & 3.626 \\
CCI & $(0.842)$ & $(0.936)^{* * *}$ \\
CCI*Risky & 0.020 & 0.027 \\
& $(0.009)^{* *}$ & $(0.012)^{* *}$ \\
$R^{2}$ & 0.043 & 0.089 \\
$N$ & $(0.027)$ & $(0.034)^{* *}$ \\
\hline & & \\
& 0.08 & 0.45 \\
\hline
\end{tabular}

${ }^{*} p<0.1 ; * * p<0.05 ; * * * p<0.0$ 


\section{Table 10. Funding markets disruptions and the shift to dollar}

The dependent variable is an indicator variable for dollar borrowing in a given quarter. ERP is the euro risk premium (the difference between 3 month Euribor and equal maturity OIS euro) and DRP is the dollar risk premium (the difference between 3 month Libor USD and equal maturity OIS USD). The other variables are as defined in Table 4. All columns include firm fixed effects, the Eurozone-US policy rate differential and its interaction with Risky, the euro-dollar exchange rate change and its interaction with Risky, the Fed target and its interaction with Risky, the borrower home country credit demand index and its interaction with Risky, and the US credit demand index and its interaction with Risky. The data cover quarters when there is a positive net percentage of Eurozone banks that report having tightened lending standards to large firms in the previous 3 months. The data are quarterly for the period 2004-Q1 to 2009-Q4. Standard errors are heteroskedasticity-robust and clustered by country*year.

\begin{tabular}{|c|c|c|c|c|}
\hline & I & II & III & IV \\
\hline & & & & $\begin{array}{l}\text { Including loans } \\
\text { purpose fixed } \\
\text { effects }\end{array}$ \\
\hline Risky & $\begin{array}{c}0.019 \\
(0.029)\end{array}$ & $\begin{array}{r}0.028 \\
(0.030)\end{array}$ & $\begin{array}{r}0.034 \\
(0.031)\end{array}$ & $\begin{array}{r}-0.020 \\
(0.058)\end{array}$ \\
\hline ERP & $\begin{array}{l}-0.053 \\
(0.028)^{*}\end{array}$ & & & $\begin{array}{r}0.015 \\
(0.026)\end{array}$ \\
\hline ERP*Risky & $\begin{array}{l}0.174 \\
(0.075)^{* *}\end{array}$ & & & $\begin{array}{l}0.147 \\
(0.055)^{* *}\end{array}$ \\
\hline DRP & & $\begin{array}{l}-0.005 \\
(0.018)\end{array}$ & & \\
\hline DRP*Risky & & $\begin{array}{r}0.059 \\
(0.036)\end{array}$ & & \\
\hline Euro basis & & & $\begin{array}{l}-0.064 \\
(0.035)^{*}\end{array}$ & \\
\hline Euro basis*Risky & & & $\begin{array}{l}0.192 \\
(0.094)^{* *}\end{array}$ & \\
\hline$R^{2}$ & 0.05 & 0.04 & 0.05 & 0.11 \\
\hline$N$ & 855 & 855 & 855 & 589 \\
\hline
\end{tabular}




\section{Table 11. The pass-through of funding costs to lending rates}

The dependent variable is the all-in-drawn spread to benchmark for Euro denominated loans. ERP is the euro risk premium (the difference between 3 month euribor and equal maturity OIS euro). The regressions include firm fixed effects, year-quarter fixed effects, log amount borrowed, loan purpose, and maturity Standard errors are heteroskedasticity-robust and clustered by country*year. The data cover quarters when there is a positive net percentage of Eurozone banks that report having tightened lending standards to large firms in the previous 3 months. The data are quarterly for the period 2004-Q1 to 2009-Q4. ${ }^{*} p<0.1$; ${ }^{* *}$ $p<0.05 ; * * * p<0.01$

\begin{tabular}{lccc}
\hline & I & II & III \\
\hline All banks & $\begin{array}{c}\text { Eurozone } \\
\text { banks only }\end{array}$ & $\begin{array}{c}\text { Non-Eurozone } \\
\text { banks in } \\
\text { syndicate }\end{array}$ \\
\hline Risky & & & 0.076 \\
ERP*Risky & 3.038 & $(1.007)$ & 0.254 \\
$R^{2}$ & $(0.450)^{* * *}$ & 3.132 & $(0.586)$ \\
$N$ & 2.148 & $(1.210)^{* *}$ & 3.421 \\
\hline
\end{tabular}




\section{Table 12. Mitigating role of non-Eurozone banks I}

The dependent variable in column I is a dummy that indicates whether the firm has borrowed during the period Q3-2007 to Q4-2009. In columns II it is the average all-in-drawn spread to benchmark charged to a firm during Q3-2007 to Q4-2009 minus the spread it paid on its last pre-crisis loan. In column III the dependent variable is the average \% of non-Eurozone banks' participation in syndicated loans the firm issued during the period Q3-2007 to Q4-2009. OLS estimates are reported. Weak bank is a dummy that takes value 1 if the firm's last pre-crisis syndicate included a Eurozone lead bank that was resolved during the crisis. The regressions include borrower country and industry fixed effects, and last pre-crisis loan characteristics: risk type, log amount borrowed, loan type, maturity, and year of issuance dummies. Further to control for demand for credit we include: a dummy for bond market access and a dummy indicating whether a debt matures during the crisis. Standard errors are heteroskedasticity-robust and clustered by country. ${ }^{*} p<0.1$; ** $p<0.05$; *** $p<0.001$

\begin{tabular}{lcrc}
\hline & I & II & III \\
\hline Access & Spread & $\begin{array}{c}\text { \% non- } \\
\text { Eurozone } \\
\text { banks }\end{array}$ \\
\hline Risky & & & 0.010 \\
Weak bank & 0.061 & -101.480 & $(0.051)$ \\
Risky*Weak bank & $(0.032)^{*}$ & $(93.483)$ & -0.008 \\
& 0.002 & 58.467 & $(0.020)$ \\
$\mathrm{R}^{2}$ & $(0.050)$ & $(23.345)^{* *}$ & 0.103 \\
$\mathrm{~N}$ & -0.106 & 238.909 & $(0.035)^{* *}$ \\
& $(0.032)^{* * *}$ & $(122.501)^{*}$ & 0.39 \\
\hline
\end{tabular}




\section{Table 13. Mitigating role of non-Eurozone banks II}

The dependent variable is the growth rate of employment for a given firm between 2008 and 2010. We report separate regressions for the full sample, the sample of risky firms (rated below investment grade), and the sample of not risky firms. Weak bank is a dummy that takes value 1 if the firm's last pre-crisis syndicate included a lead bank that was resolved during the crisis. \% non-Eurozone banks is the percentage of non-Eurozone arrangers in the last pre-crisis syndicate. We include 2-digit SIC code fixed effects, log total assets, log firm age, and last pre-crisis loan characteristics: the spread, maturity, loan type, and year of issuance. Further, to control for demand for credit we include: a dummy for bond market access, a dummy indicating whether a debt is maturing during the crisis, the ratio of cash over total assets in 2007, and reliance on trade credit in 2007 (measured by accounts payable scaled by total sales). In columns VI and VII we instrument \% non-Eurozone banks by the propensities of the last pre-crisis loan arranger(s) to co-syndicate with US, UK, Japanese, and other non-Eurozone banks during 2004-2013. Errors are clustered by country. ${ }^{*} p<0.1 ; * * p<0.05 ; * * * p<0.01$

\begin{tabular}{|c|c|c|c|c|c|c|c|}
\hline & $\mathrm{I}$ & II & III & IV & $\mathrm{V}$ & VI & VII \\
\hline & Full Sample & Risky & Not Risky & Risky & Not Risky & Risky & Not Risky \\
\hline & OLS & OLS & OLS & OLS & OLS & 2SLS & 2SLS \\
\hline Risky & $\begin{array}{r}0.065 \\
(0.053)\end{array}$ & & & & & & \\
\hline Weak bank & $\begin{array}{r}0.011 \\
(0.029)\end{array}$ & $\begin{array}{l}-0.170 \\
(0.049)^{* * *}\end{array}$ & $\begin{array}{r}0.012 \\
(0.031)\end{array}$ & $\begin{array}{l}-0.238 \\
(0.071)^{* * *}\end{array}$ & $\begin{array}{r}0.040 \\
(0.046)\end{array}$ & $\begin{array}{l}-0.332 \\
(0.105)^{* * *}\end{array}$ & $\begin{array}{r}-0.040 \\
(0.064)\end{array}$ \\
\hline Risky*Weak bank & $\begin{array}{l}-0.174 \\
(0.050)^{* * *}\end{array}$ & & & & & & \\
\hline \% non-Eurozone banks & & $\begin{array}{r}0.079 \\
(0.055)\end{array}$ & $\begin{array}{r}0.043 \\
(0.091)\end{array}$ & $\begin{array}{r}-0.098 \\
(0.125)\end{array}$ & $\begin{array}{r}0.218 \\
(0.215)\end{array}$ & $\begin{array}{r}-0.226 \\
(0.170)\end{array}$ & $\begin{array}{r}-0.549 \\
(0.586)\end{array}$ \\
\hline Weak bank*\% non-Eurozone banks & & & & $\begin{array}{c}0.229 \\
(0.116)^{*}\end{array}$ & $\begin{array}{l}-0.216 \\
(0.250)\end{array}$ & $\begin{array}{l}0.558 \\
(0.198)^{* * *}\end{array}$ & $\begin{array}{r}0.419 \\
(0.519)\end{array}$ \\
\hline First-stage F-statistic & & & & & & 58.06 & 10.38 \\
\hline J-statistic p-value & & & & & & 0.33 & 0.54 \\
\hline$R^{2}$ & 0.11 & 0.38 & 0.11 & 0.39 & 0.11 & & \\
\hline$N$ & 450 & 126 & 324 & 126 & 324 & 126 & 324 \\
\hline
\end{tabular}

